\title{
Luchar contra el narcotráfico: comunicación política electoral sobre las drogas ilícitas en Argentina
}

\author{
Cristian Manchego Cárdenas \\ Instituto de Investigaciones Gino Germani, Facultad de Ciencias Sociales, \\ Universidad de Buenos Aires. \\ cristianmanchegoca@gmail.com \\ Fecha de finalización: 1 de agosto de 2020 \\ Recibido: 20 de agosto de 2020 . \\ Aceptado: 9 de diciembre de 2020. \\ DOI: https://doi.org/10.26422/aucom.2020.0902.man
}

\section{Resumen}

En la Argentina, el narcotráfico ha atravesado desde hace décadas los discursos y prácticas políticas nacionales y ha sido abordado sobre todo desde un enfoque punitivo y prohibicionista. En la campaña electoral para las elecciones presidenciales de 2015, el tráfico y uso de drogas ilícitas fue un tópico de relevancia para la agenda política electoral. Los candidatos intervinieron públicamente sobre cómo abordarían la problemática y diagnosticaron el impacto del fenómeno en la sociedad. Este artículo analiza el discurso político sobre el narcotráfico durante la campaña presidencial de 2015 en Argentina y presenta algunas variables analíticas a trabajar en futuras investigaciones abocadas al discurso sobre la narcocriminalidad y el consumo de sustancias ilícitas. A partir de la revisión de spots audiovisuales, debates presidenciales, entrevistas televisadas, folletería y plataformas electorales de las fuerzas políticas que participaron en la primera y segunda vuelta electoral de 2015, se define de qué modo los candidatos presidenciales trataron el tema e interpelaron a la ciudadanía. Se concluye que el discurso político sobre el narcotráfico se caracterizó por cuatro líneas discursivas principales: la intervención en clave armada, la territorialización del fenómeno de las drogas ilícitas, la gestión de los castigos desde un enfoque legal-normativo y la apelación a la ciudadanía víctima de los perjuicios del narcotráfico, la inseguridad urbana, la corrupción pública y la ineficacia del Gobierno de turno.

Palabras clave: comunicación política, narcotráfico, drogas ilícitas, campañas electorales.

\section{The fight against drug trafficking: Electoral political communication regarding illegal drugs in Argentina}

\section{Abstract}

In Argentina, the topic of drug trafficking has, for decades, been part of the national political conversation. For the most part, it has been approached from punitive and prohibitionist standpoints. In the runup to the 2015 presidential elections, the consumption and distribution of illegal drugs became a relevant part of the campaign agenda. Candidates stated how they would deal with the problem, if elected, and diagnosed the social impact of the issue. This arti- 
Cristian Manchego Cárdenas

Luchar contra el narcotráfico: comunicación política electoral sobre las drogas ilícitas en Argentina

cle, then, analyzes the political discourse on drug trafficking during the above electoral period in Argentina, and offers a few analytical variables worth considering in future investigations on drug-related crime and the consumption of illegal substances. By reviewing audiovisual ads, presidential debates, television interviews, pamphlets, and the electoral platforms of the parties and coalitions involved in the first and second rounds of the 2015 elections, we define how presidential hopefuls dealt with the topic at hand and reached out to their potential electors. We conclude that the political discourse on drug trafficking was characterized by four main discursive through-lines: the promise of armed intervention, the territorialization of the illegal drug phenomenon, the application of legal-normative punishment, and the appeal to a citizenship victimized by drug trafficking, urban insecurity, political corruption, and the inefficiency of the incumbent government.

Keywords: political communication, drug trafficking, illegal drugs, electoral campaigns.

\section{Luta contra o narcotráfico: Comunicação política eleitoral sobre drogas ilícitas na Argentina}

\section{Resumo}

Na Argentina, o narcotráfico atravessa os discursos e práticas políticas nacionais há décadas e é abordado, sobretudo, com uma abordagem punitiva e proibicionista. Na campanha eleitoral para as eleições presidenciais de 2015, o tráfico e uso de drogas ilícitas foi um tema relevante para a agenda política eleitoral. Os candidatos intervieram publicamente sobre como abordariam o problema e diagnosticaram o impacto do fenômeno na sociedade. Este artigo analisa o discurso político sobre o tráfico de drogas durante a campanha presidencial de 2015 na Argentina e apresenta algumas variáveis a serem trabalhadas em pesquisas futuras dedicadas ao discurso sobre a narcocriminalidade e o consumo de substâncias ilícitas. Com base na revisão de spots audiovisuais, debates presidenciais, entrevistas televisivas, brochuras e plataformas eleitorais das forças políticas que participaram no primeiro e no segundo turnos eleitorais de 2015, define-se como os postulantes trataram o assunto para os cidadãos. Conclui-se que o discurso político sobre o narcotráfico se caracterizou por quatro linhas discursivas principais: intervenção em um código armado; a territorialização do fenômeno das drogas ilícitas, a gestão das penas desde um enfoque jurídico-normativo e a interpelação aos cidadãos vítimas do narcotráfico, da insegurança urbana, da corrupção pública e da ineficácia do então Governo Nacional.

Palavras chave: comunicação política, narcotráfico, drogas ilícitas, campanhas eleitorais.

\section{Introducción ${ }^{1}$}

El fenómeno del narcotráfico ha sido materia de políticas gubernamentales y de discusión pública en los últimos años en Argentina. Las lógicas prohibicionistas y punitivas sobre el narcotráfico han atravesado los discursos y prácticas políticas nacionales desde hace décadas, pero se han profundizado en el contexto de la agudización de la fragilidad del Estado argentino ante el crimen organizado (Frederic, 2020) y en el marco de la emergencia de las nuevas amenazas globales (Tokatlian, 2018). A pesar de las experiencias negativas de la denominada guerra contra el narcotráfico, llevada

\footnotetext{
Un agradecimiento especial a Mercedes Calzado y a Yamila Gómez por sus lecturas y comentarios realizados durante el proceso de investigación, que dio como resultado el presente artículo.
} 
a cabo por naciones como México y Estados Unidos (Ángel, 2017; Keefer y Loayza, 2010), el Gobierno argentino ha impulsado desde 2011 -pero, sobre todo, a partir de 2015- la intervención de las Fuerzas Armadas en la lucha contra las drogas ilícitas y, en este sentido, se ha vulnerado la demarcación entre las acciones de la seguridad pública y la seguridad nacional (Sain, 2018).

Si bien el narcotráfico forma parte de la agenda política argentina contemporánea, particularmente las campañas electorales se configuran como momentos oportunos para analizar de qué modo el campo político interpela a la ciudadanía y se identifica con sus preocupaciones sobre cuestiones securitarias (Calzado, 2020; Dallorso y Seghezzo, 2015; Calzado, Fernández y Lio, 2014a; Fleitas Ortiz de Rosas, 2014). Examinar las características discursivas sobre una cuestión criminal como el narcotráfico permite profundizar en las relaciones de poder simbólico que constituyen las palabras y los posicionamientos de los candidatos argentinos (Calzado, 2020). Estos discursos electorales no se corresponden únicamente con la realidad nacional, ${ }^{2}$ sino que también fueron analizados en otros países, particularmente en clave criminológica (Beckett, 1997; Garland, 2005; Simon, 2011). De hecho, existe una tendencia política a acudir al crimen y al miedo como tópico electoral que se constata tanto en naciones latinoamericanas como en Estados Unidos (Chevigny, 2003).

El narcotráfico como objeto discursivo en el campo político o periodístico argentino, así como en las percepciones ciudadanas, forma parte de investigaciones ocupadas por la mediatización y el discurso de la criminalidad e inseguridad urbana en el país. Algunos de estos estudios han profundizado en la comprensión de la producción o circulación o recepción de la noticia policial de formato escrito o audiovisual (Baquero, 2017; Focás, 2019; Focás y Galar 2016; Heram y Gago 2019; Luchessi y Martini 2004; Silvera y Natalevich 2012). Desde esta literatura, el narcotráfico es retomado en función de los debates acerca del sentimiento de inseguridad, el rol de los medios de comunicación, la instauración mediática del miedo y la penetración del tema de la inseguridad en la ciudadanía. Tomando en cuenta este amplio campo de análisis, el presente estudio tiene la particularidad de centrarse en la temática del narcotráfico y conversa, en cierto sentido, con los trabajos señalados anteriormente.

En la campaña electoral para la elección presidencial de 2015 en Argentina, el narcotráfico fue posicionado por los candidatos como una problemática que el Gobierno venidero tenía que enfrentar. La relevancia del tema de las drogas ilícitas en la agenda pública determinó la producción de intervenciones políticas específicas sobre el tópico. Como parte de sus estrategias de comunicación, los candidatos presidenciales

\footnotetext{
La inseguridad ciudadana es una de las preocupaciones más relevantes de los argentinos. En 2015, por ejemplo, el $39 \%$ de los encuestados por Latinobarómetro (2015) aseguró que esta cuestión era uno de los problemas principales del país, un diagnóstico que se repitió en años anteriores.
} 
Cristian Manchego Cárdenas

Luchar contra el narcotráfico: comunicación política electoral sobre las drogas ilícitas en Argentina

intervinieron en el debate público acerca de cómo combatir el narcotráfico y desarrollaron diagnósticos de situación en torno a la dimensión de su impacto en la sociedad. Asimismo, según algunos estudios de opinión pública, en 2015, los argentinos estaban en sintonía con la agenda política. La droga había aumentado en los barrios y era considerada una problemática de gravedad. ${ }^{3}$

Los candidatos abordaron el "narcotráfico" desde sus plataformas electorales, actos públicos, entrevistas televisadas, plataformas webs, redes sociales y spots audiovisuales, entre otras mediatizaciones. Los medios de comunicación también registraron la relevancia del tópico a partir de su mayor cobertura noticiosa. Las menciones a los delitos vinculados con el narcotráfico aumentaron en los meses de campaña de 2015 respecto al total de este tipo de información periodística reportado en los meses preelectorales. A medida que la campaña presidencial fue evolucionando, las noticias sobre "tenencia y tráfico de drogas" fueron ganando presencia en la agenda mediática y pasaron a convertirse en central durante los meses electorales. ${ }^{4}$

\section{Metodología}

Revisamos en spots audiovisuales, debates presidenciales, entrevistas televisadas, plataformas electorales y folletería regularidades temáticas en torno al "tráfico y uso de drogas ilícitas". ${ }^{5}$ El objetivo de la investigación es explorar el modo en el que el discurso político argentino abordó la lucha contra el narcotráfico en la campaña presidencial de 2015. Los objetivos específicos son: 1) describir y analizar las modalidades enunciativas y temáticas del discurso sobre el narcotráfico de los candidatos presidenciales de $2015 ; 2)$ identificar las similitudes y diferencias de las comunicaciones sobre el tópico del narcotráfico realizadas por los distintos representantes de las fuerzas políticas; y 3 ) establecer y definir tipologías del discurso político electoral sobre el tráfico y uso de drogas ilícitas en Argentina.

Para abordar nuestro objeto de estudio, empleamos técnicas de análisis del discurso (Verón, 1993, 2003), revisamos las entidades y los componentes de la comuni-

\footnotetext{
En 2015, 8 de cada 10 encuestados consideraron el avance del narcotráfico como "grave" o "muy grave" (Universidad Argentina de la Empresa, 2017).

4 Del total de las notas gráficas que reportaron este delito, el $30 \%$ fue publicado durante los primeros seis meses de 2015, mientras que ese porcentaje aumentó a 70\% en época de campaña, es decir, de julio a diciembre del mismo año (Observatorio de Medios del Centro de Estudios Latinoamericanos, 2016).

5 Para esta instancia de la investigación no abordamos la propaganda política en redes sociales. Esperamos, en futuras investigaciones, ampliar el material y las perspectivas conceptuales que ayuden al análisis de lo que sucedió en 2015 con los discursos políticos sobre el narcotráfico en las redes sociales. Teniendo en cuenta esta salvedad, es preciso aclarar que los spots audiovisuales que forman parte de nuestro corpus fueron transmitidos a través de medios televisivos nacionales y, posteriormente, publicados en los canales digitales de las fuerzas políticas en competencia. Solo con el fin de que el público lector de esta investigación tenga disponibilidad a ese material de estudio, se comparten los enlaces a esos videos registrados en YouTube, lo cual no implica que nuestro estudio aborde ese espacio digital.
} 
cación política (Verón, 1996) y los rasgos lingüísticos y extralingüísticos del material de análisis (Mangone y Warley, 1994). El corpus comprende las comunicaciones de los candidatos Mauricio Macri (Cambiemos), Daniel Scioli (Frente para la Victoria), Sergio Massa (Unidos por Una Alternativa), Margarita Stolbizer (Progresistas), Adolfo Rodríguez Saá (Compromiso Federal) y Nicolás del Caño (Frente de Izquierda de los Trabajadores). Si bien trabajamos sobre todo con material de los primeros tres candidatos mencionados, debido a que fueron quienes más votos obtuvieron en la primera vuelta electoral, ${ }^{6}$ no perdemos de vista las discursividades de sus adversarios, principalmente las del representante de la fuerza de izquierda. Esto permite definir de mejor forma las tensiones e invariantes del discurso político electoral sobre la narcocriminalidad. El periodo de selección del corpus abarca desde el 30 de septiembre hasta el 23 de octubre y del 6 de noviembre al 21 de noviembre de 2015, tiempo estipulado por la Cámara Nacional Electoral y por la Justicia Nacional Electoral para la circulación de material de campaña en medios de comunicación audiovisuales.

¿Cómo es el tratamiento del tópico "narcotráfico" en los discursos de los candidatos presidenciales de 2015? ¿Qué significa luchar contra el narcotráfico para el discurso político electoral de esa campaña? ¿Qué invariantes discursivas se registran entre los candidatos de las distintas fuerzas políticas? ¿Cómo se interpela a la ciudadanía sobre la cuestión del narcotráfico? A partir del abordaje de estas preguntas que guiaron el desarrollo de nuestra investigación, obtuvimos los resultados que se presentan en los apartados siguientes. En tal sentido, los hallazgos se elaboraron a partir de la identificación de las modalidades enunciativas y temáticas de las comunicaciones sobre el narcotráfico, como así también del reconocimiento de las similitudes y diferencias correspondientes a las intervenciones de los representantes de cada fuerza política.

A modo de hipótesis, asumimos que los candidatos presidenciales de 2015 abordaron la cuestión de las drogas a partir de cuatro líneas discursivas clave: la intervención armada del Estado, la territorialización del fenómeno de las drogas ilícitas, la gestión de los castigos desde un enfoque legal-normativo y la apelación a la ciudadanía víctima de la inseguridad y del Gobierno de turno. Estas categorías son rasgos transversales a las estrategias de comunicación llevadas a cabo por el arco político en competencia para la campaña presidencial de ese año. No se trata de modalidades excluyentes entre las fuerzas políticas, ya que los candidatos presidenciales se adhirieron, en menor o mayor medida, a estos ejes discursivos para tratar el tema de las drogas ante la ciudadanía. Sin embargo, a lo largo de los siguientes apartados veremos cómo cada tipología presenta rasgos particulares y varía en función del tratamiento del tema que realiza el enunciador político según el lugar que ocupa en el juego electoral (ya sea una coalición

6 En esos comicios, el candidato Daniel Scioli obtuvo el 37,08\% de los votos escrutados. Mauricio Macri quedó en segundo lugar con el 34,15\% y Sergio Massa obtuvo el 21,39\% del total de los votos (Gobierno de Argentina, 2015). 
Cristian Manchego Cárdenas

Luchar contra el narcotráfico: comunicación política electoral sobre las drogas ilícitas en Argentina

en oposición al Gobierno de turno o el frente oficialista), así como también a partir sus trayectorias de abordaje a temas securitarios (como es el caso del frente de izquierda).

\section{El combate en clave armada}

El rol de las fuerzas de seguridad y de las Fuerzas Armadas en el combate contra la narcocriminalidad ocupó un lugar central en el discurso político durante la campaña presidencial de 2015. Gran parte de los candidatos presidenciales propuso intervenir en la problemática a partir de la conformación de un Gobierno eficiente que estableciera como prioridad el uso del brazo armado del Estado. En el discurso electoral, gobernar la problemática de las drogas ilícitas implicó presentar, en clave programática, la conformación de un Estado presente: un Gobierno que se involucrara en la lucha contra el narcotráfico era, en gran medida, un Estado que actuaría con mano dura. De allí que en la propaganda audiovisual se visualizaran imágenes de artefactos militares y policiales para referir la batalla contra el narcotráfico que los candidatos prometían.

La adjetivación del narcotráfico como un enemigo de carácter extranacional, pero, a su vez, de índole interna, se constituyó como antesala a la invocación al rol de las fuerzas del orden. Los diagnósticos electorales señalaron que la droga había penetrado en diversos ámbitos de la sociedad. Un enemigo con "poder", "dinero" y al que "no le importa cobrarse vidas", mencionaba el candidato Sergio Massa en el spot Seguridad Ampliada (Observatorio Comunicación, Política y Seguridad, 2016a). El comercial aludía directamente a favor de la intromisión del Ejército, la Fuerza Aérea y la Marina en el combate contra el narcotráfico. A partir de la complejidad del problema y de las dimensiones de los perjuicios a la seguridad pública, se presenta este modo de significación en clave armada. La droga se convierte en uno de los peores males sociales y causante de muchos otros. El aumento de la violencia urbana, de los delitos, de la corrupción en el Estado se explica en los discursos presidencialistas en cierta medida por la presencia del comercio ilegal de drogas y de su uso indebido.

La lucha armada contra el narcotráfico implica abordar la profesionalización de las fuerzas de seguridad desde un enfoque cualitativo y cuantitativo. Las discursividades del candidato Daniel Scioli siguen esta línea argumentativa al respecto de la revalorización de la formación de los agentes policiales y el incremento del número de efectivos de seguridad. "La Argentina necesitaba trabajar más en la lucha contra la droga y la inseguridad. Ahora vamos por 100 mil nuevos policías locales y agentes federales. Eso es el desarrollo" (Observatorio Comunicación, Política y Seguridad, 2016), mencionaba uno de los spots del Frente para la Victoria que abordaba la consigna de las fuerzas policiales y el narcotráfico (Figura 1). En el audiovisual, una multitud de agentes enfilados y listos para la acción exponían el profesionalismo necesario para intervenir ante el enemigo. En el plano enunciativo, el líder del proyecto antinarcóticos que el país 
requería se mostraba con capacidad resolutiva; podía dirigir y comandar un ejército de combatientes representados en imágenes.

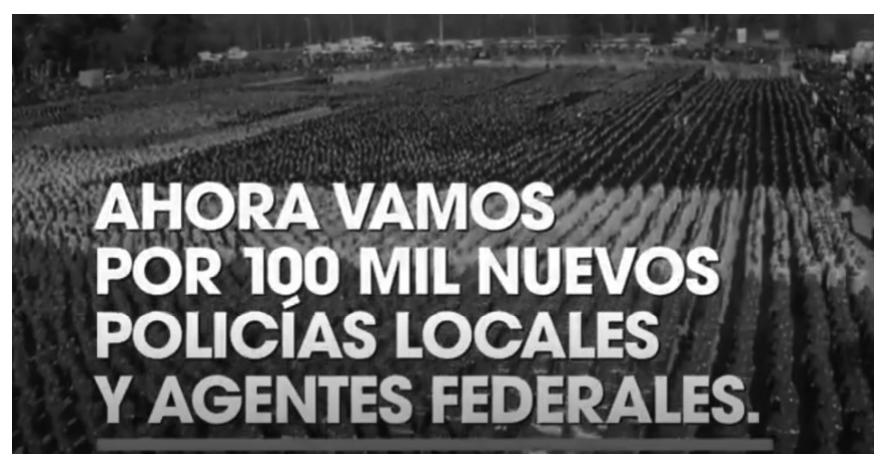

Figura 1. Spot del Frente para la Victoria sobre 100 mil nuevos agentes. (Fuente: Observatorio Comunicación, Política y Seguridad, 2016).

Las imágenes de combate traslucen sentidos en juego sobre el modo de intervención estatal. Un Estado presente implica presentar en imágenes más y mejores efectivos de seguridad: policías preparados para el combate. Cientos de efectivos de seguridad eran plasmados en los audiovisuales de las fuerzas políticas que trataban el tópico. Para vivir en paz y estar seguros, el Estado tendría que actuar en estos términos. "Para enfrentar a un ejército tan poderoso, extranacional, como es el del narcotráfico, en la Argentina tenemos que usar todas las herramientas y el poder del Estado" (Argentina Debate, 2015). Las declaraciones de Sergio Massa en el primer debate presidencial caracterizaron la magnitud del oponente. La descripción de los aspectos de la fuerza antagónica se convirtieron en la antesala de la principal proclama del candidato: el uso de las Fuerzas Armadas en el combate contra el narcotráfico. Ante el poderío militar del contrincante, los resguardos del Estado se fortalecen.

Eficiencia y experiencia en la gestión pública se constituyeron como dos valores incorporados en los discursos de los candidatos presidenciales. Desde allí tomaron distancia de una imagen que los presentara como inactivos frente al delito. Su objetivo era construir un panorama social esperanzador libre de las drogas ilícitas. El proyecto incluía también enfrentar la violencia urbana y la inseguridad: problemáticas ligadas al tráfico, pero, sobre todo, al uso de sustancias. Para estos discursos, la presencia de las drogas en el país es inaceptable y, en consecuencia, el Estado tendría que actuar con mano dura. Históricamente, las lógicas prohibicionistas y represivas se han impregnado en nuestros modos de entender y hablar sobre los psicotóxicos (Tokatlian, 2010a, 2010b, 2018). El tratamiento sobre el narcotráfico durante la campaña presidencial de 2015 no era ajeno a esta caracterización. Gran parte del arco político entendía que la lucha era inminente y que el proyecto implicaba la intervención pública en clave armada. De aquí que el uso de 
Cristian Manchego Cárdenas

Luchar contra el narcotráfico: comunicación política electoral sobre las drogas ilícitas en Argentina

terminología bélica -como "guerra", "mano dura”, “tolerancia cero", “derribo de aviones", "con todas nuestras fuerzas" - fuera una constante de los candidatos.

Garland (2005) menciona que las medidas con las cuales se identifican los funcionarios electos deben ser penológicamente creíbles, ya que los candidatos deben gozar de credibilidad política y apoyo popular. "En la selección de respuestas políticas resultan más atractivas aquellas que pueden ser más fácilmente representadas como decididas, inteligentes y efectivas o simbólicas" (Garland, 2005, p. 191). Si bien el análisis del investigador se focaliza en las tres últimas décadas de Estados Unidos e Inglaterra, su aporte resulta igualmente enriquecedor para reflexionar acerca de lo que sucede en países como Argentina, sobre todo respecto a cómo los fenómenos sociales y culturales configuran las prácticas y discursos políticos que interpelan a los ciudadanos atemorizados que podrían no simpatizar con políticos que traten a medias tintas los tópicos de preocupación social.

El diagnóstico común es la ineficiencia e impunidad estatal. El entonces Gobierno nacional se configuró como principal figura adversativa de gran parte de los discursos electorales. Se remarcaron rasgos tales como la carencia de toma de decisión e incluso la complicidad con el delito. Así, para mostrar una versión distinta a un Gobierno desvalido frente al narcotráfico, los principales candidatos visibilizaron las políticas en materia de seguridad que habían llevado a cabo en sus respectivas gestiones municipales o provinciales. La figura de un Estado ausente se conjugó bien con estas estrategias discursivas y se apuntó a descalificar a la gestión de turno debido a su ineficaz proyecto antinarcóticos. Un Estado incluso permisivo. Las intervenciones de los candidatos opositores al entonces Gobierno remarcaron el mal social y la inacción estatal que subyacía. En contraposición a esta figura de Estado ausente, los candidatos conformaron un discurso de eficiencia por haber estado en cargos de gestión (municipal o provincial), desde los cuales tenían una comunicación y una práctica muy activa frente a la inseguridad en general y al narcotráfico en particular.

El candidato del partido oficialista, Daniel Scioli, planteó su estrategia de comunicación en un contexto en el que el Gobierno nacional era duramente criticado por su accionar ante las drogas ilícitas. Visibilizó los logros de su administración como gobernador de la provincia de Buenos Aires y evitó mostrarse como continuista de las políticas securitarias de la entonces presidenta Cristina Fernández. Durante múltiples hechos de incautaciones de drogas realizadas por las fuerzas de seguridad en la provincia durante los meses electorales, fue Daniel Scioli quien presentaba los resultados de los operativos policiales ante los medios de comunicación. Este modo de mostrarse con capacidad de gestión también se evidenció durante sus entrevistas televisadas. "Mi propuesta no son palabras o realidades obvias, son las acciones que vamos llevando adelante" (Daniel Scioli, 2015), mencionaba el candidato en el programa A Dos Voces 
(TN). La experiencia de gobierno en la provincia más poblada del país lo colocaba en el plano del político en acción y con capacidad de liderazgo.

La intervención política en torno al rol de las fuerzas del orden implica, principalmente, adoptar señales de compromiso con un Gobierno fuerte y responsable frente a la criminalidad organizada. Así, se le otorga especial valor a la implementación de políticas en materia de seguridad en períodos de gestión pública. Por ejemplo, Daniel Scioli se refirió enfáticamente a la creación de la policía local y a la "mayor incorporación cualitativa y cuantitativa" (Argentina Debate, 2015b) de efectivos durante su gobernación en la provincia de Buenos Aires. En el caso de Mauricio Macri, predominó la política de creación de la Policía Metropolitana (actual Policía de la Ciudad) y la instalación de cámaras de seguridad. Sergio Massa hizo lo propio a través de la visibilización de los "éxitos" en el Municipio Tigre, el cual había gestionado: "Logramos bajar los robos de autos, venta de drogas y entraderas", mencionaba el candidato en uno de sus spots (Observatorio Comunicación, Política y Seguridad, 2016).

Para la mayoría de los candidatos opositores al partido gobernante, el narcotráfico había aumentado debido a la desidia del Gobierno de Cristina Fernández ante la problemática de las drogas. De allí a que gran parte de las propuestas electorales giraran en torno a lo que el Estado debía hacer en contraposición a lo realizado por el Gobierno kirchnerista. El candidato del oficialismo, Daniel Scioli, no fue reacio a diagnosticar y replantear los modos de enfrentar la problemática. El Frente para la Victoria reconocía en uno de sus spots que la lucha contra el narcotráfico no estaba ganada, pero tampoco perdida (Daniel Scioli, 2015a). Se trataba de un proceso en marcha: un Estado presente, aunque mejorable. Si bien Daniel Scioli no pudo desconocer el tópico dada la relevancia que tuvo para esta campaña presidencial, adoptó esta estrategia comunicativa para abordar el tema desde su posición de candidato del partido oficialista.

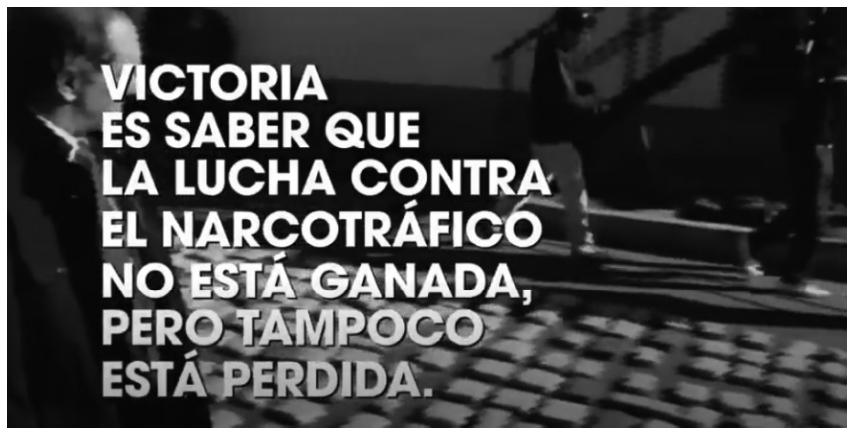

Figura 2. Spot del Frente para la Victoria sobre la lucha contra el narcotráfico. (Fuente: Daniel Scioli, 2015a).

El discurso político argentino en la campaña de 2015 abordaba el tema del narcotráfico a través de su problematización al respecto de otras cuestiones sociales. La lu- 
Cristian Manchego Cárdenas

Luchar contra el narcotráfico: comunicación política electoral sobre las drogas ilícitas en Argentina

cha en clave armada se justificaba a partir del vínculo construido entre el tópico de las drogas y el delito urbano y la violencia."El narcotráfico está poniendo en crisis nuestro estilo de vida, nuestras familias, nos ha llenado de violencia en nuestros barrios y está corrompiendo nuestras instituciones, comprando política, justicia, policía", mencionaba Mauricio Macri en una de sus propagandas (Mauricio Macri, 2015). Esto, a pesar de que el binomio narcotráfico/consumo de drogas no era considerado como una de las mayores preocupaciones para los ciudadanos en Argentina. ${ }^{7}$ Para el candidato de Cambiemos, el narcotráfico estaba corrompiendo el ideal funcionamiento de diversos ámbitos en la sociedad: espacios íntimos como la familia, círculos públicos como los "barrios" y las instituciones estatales. ¿Qué significa luchar contra el narcotráfico?: combatir la corrupción, sobre todo la enraizada en las agencias de seguridad y en la política. Que el narcotráfico y el uso de drogas fueran presentados como constitutivos del problema del delito y la violencia urbana no es un hecho menor. Este diagnóstico se adecúa a las actuales retóricas políticas que ponen el acento en una preocupación social persistente para los argentinos: la inseguridad ciudadana. ${ }^{8}$ De hecho, ya en la elección legislativa de 2013, el narcotráfico había surgido como una cuestión prioritaria para configurar la definición de la inseguridad (Calzado, Fernández y Lio, 2014a).

La inseguridad, junto con el narcotráfico, son "los flagelos más grandes que tenemos en este momento" (Argentina Debate, 2015a), mencionaba el candidato Rodríguez Saá en el primer debate presidencial. El diagnóstico común en los discursos políticos plantea la situación de crisis de seguridad que convoca a actuar con mano dura. El discurso político construye escenarios de emergencia social debido al vínculo entre el negocio ilegal de las drogas, el uso de sustancias y la violencia urbana. En este sentido, la intervención de las Fuerzas Armadas y la profesionalización de las fuerzas de seguridad se constituyeron como ejes centrales del combate. En los spots audiovisuales de los candidatos Mauricio Macri, Daniel Scioli y Sergio Massa, el uso de artefactos militares y policiales era una constante narrativa. Aeronaves de guerra, patrulleros, helicópteros; las figuras representaban un combate con mano dura. Las propuestas y las imágenes invitaban a reflexionar acerca de los entramados sociales que conforman el control del delito en el país y en gran parte de las sociedades occidentales.

En 2011, el 2,3\% de los encuestados consideraron al "narcotráfico" y al "consumo de drogas" como las problemáticas más importantes en el país; en 2013, el 2,1\%; y en 2015, el 1,9\%. Los resultados de la encuesta son con base en la pregunta: “En su opinión, ¿cuál considera usted que es el problema más importante en el país?” (Latinobarómetro, 2015). El tema "drogas" no es considerado como prioritario en Argentina. Sin embargo, hay que tomar en cuenta que este tipo de "preferencias" de los encuestados exige anteponer algunas problemáticas sociales en relación con otras lo cual conlleva a que gran parte del país muestre un mayor o menor enfoque hacia diversas cuestiones según el contexto social y no necesariamente priorice su atención hacia el "avance de la droga".

8 Desde el campo académico, algunos investigadores ponen en duda el vínculo entre el uso de drogas y el aumento de la criminalidad, aduciendo ausencia de investigaciones serias que constaten el supuesto (Centro de Estudios Legales y Sociales, 2016; Dammert, 2009). 
Austral Comunicación

Volumen 9, número 2 (Diciembre de 2020):481-518. ISSN 2313-9129

De nuestra investigación surge que el discurso político electoral sobre el narcotráfico expone también una postura no represiva del Estado. Para esta mirada, la intromisión de las Fuerzas Armadas es rechazada tajantemente y el rol de las fuerzas de seguridad en el combate contra el narcotráfico es cuestionado. Las agencias encargadas de administrar el control de la seguridad urbana son señaladas como cómplices del negocio ilegal de las drogas. En consecuencia, el Estado presente no podría combatir el narcotráfico con mafias policiales que son señaladas de perpetuar la represión a quienes serían las verdaderas víctimas del delito: los jóvenes y los pobres. Estado ausente no significa solamente carencia de protección a los ciudadanos, sino también responsabilidad de las violaciones a los derechos humanos cometidas por los agentes de las fuerzas de seguridad. El abordaje del candidato del Frente de Izquierda y de los Trabajadores es un buen ejemplo de esta faceta discursiva, aunque no es ampliamente incluida en las comunicaciones de todos los espacios políticos.

En definitiva, las situaciones de alarma social devenidas por la inseguridad, la violencia y otras problemáticas ligadas al narcotráfico en el país demandan la inmediata reacción de un Estado presente con mano dura. El uso de las Fuerzas Armadas y la profesionalización de las fuerzas de seguridad catalizan flujos discursivos que -con variantes y contrastes específicos-, reducen el debate al uso de esas fuerzas como accionar represivo contra el narcotráfico. La apelación hacía una mayor intervención policial se contrapone con la postura que desaprueba este tipo de medidas. Sea como fuere, el rol del brazo armado del Estado se constituye como un debate que se presenta indefectiblemente al momento de abordar el tema del narcotráfico. En esta línea, los discursos políticos construyen la figura del futuro presidente del país a partir de cualidades como la eficiencia, la capacidad de acción y, sobre todo, la experiencia en gestión gubernamental. De aquí que los principales candidatos (Scioli, Macri y Massa) se volcaran a visibilizar las políticas en materia de seguridad que habían implementado durante sus respectivos mandatos municipales o provinciales.

\section{Territorios y peligro}

Los discursos electorales sobre el narcotráfico constituyeron un mapa nacional de riesgos: focos de conflicto en los que el Estado tenía que acentuar su presencia armada, para resguardar el orden en determinados ámbitos de la urbe y evitar la contaminación territorial de la narcocriminalidad. La irrupción del tópico del narcotráfico en las enunciaciones políticas reveló algunos modos de configuración del Estado imaginado. "Frontera porosa" y "colador" fueron metáforas comunes para referir los límites nacionales en peligro. Un Estado que liderara la batalla contra el narcotráfico tenía que asumir la importancia de intervenir en el cuidado de la soberanía nacional. "Vamos a empezar por discutir y asignar las competencias. La Gendarmería a la frontera [...] 
Cristian Manchego Cárdenas

Luchar contra el narcotráfico: comunicación política electoral sobre las drogas ilícitas en Argentina

cada uno, a cumplir su tarea" (Argentina Debate, 2015a). Las declaraciones del candidato Adolfo Rodríguez Saá se realizaron durante el primer debate presidencial. Las fronteras nacionales son entendidas como espacios sin control, carentes del resguardo del Estado. Las instituciones encargadas de administrar el control público son cuestionadas por no cumplir fehacientemente su responsabilidad como agentes protectores de riesgos ajenos al nosotros-nacional. Peligrosidades que se filtran a través de las porosidades en las demarcaciones nacionales.

En los significantes que analizamos, la cuestión del tráfico de droga pasa de tener factores causales internos a ser un problema de origen foráneo. Las enunciaciones políticas aluden implícitamente al narcotráfico como un asunto ajeno al nosotros-nacional. Se trata de una cuestión que si bien se ha expandido en el territorio nacional a causa de la ineficacia del Estado, parte de la responsabilidad está por fuera de las demarcaciones soberanas. Mayormente se habla de la situación de emergencia de los pasos fronterizos en el norte argentino: en Tartagal, La Quiaca (puntos fronterizos argentino-boliviano) y en Misiones (provincia argentina que limita con Paraguay). Las intervenciones políticas depositan interés por la protección de las fronteras nacionales como medida de lucha contra el narcotráfico. Daniel Scioli, por ejemplo, trabajó este punto. Prometió blindar las fronteras con las Fuerzas Armadas para combatir el narcotráfico. El apego del candidato a la medida se hizo explícito sobre todo tras la primera vuelta, en claro guiño de coincidencia con Sergio Massa, quien no había pasado al balotaje y planteaba la movilización del Ejército en las zonas fronterizas del país $\mathrm{y}$ en los barrios populares. El cuidado de las fronteras nacionales y, vinculada a esto, la propuesta sobre el derribo de aviones hostiles que transiten por el espacio aéreo argentino como intervención militar ante el narcotráfico no son propuestas exclusivas de las discursividades políticas. Los ciudadanos también consideran que "Tener un mayor control en las fronteras y aeropuertos" (Universidad Argentina de la Empresa, 2017, p. 15) es una de las medidas más adecuadas para el proyecto antinarcóticos. ${ }^{9}$ En los discursos electorales de los candidatos de 2015, el constante uso de significantes y consignas tales como "territorio", "colador", "cierre de frontera" y "bloqueo de frontera" soslayaba el regreso de un (¿viejo?) actor de las discursividades políticas en relación con ciertas problemáticas sociales: el inmigrante. Sin nombrarlo, la idea de un territorio en peligro lo ubica en el plano de la sospecha y la amenaza.

\footnotetext{
En 2017, el 38\% de los encuestados manifestó un interés por esta opción solo después de “Tener leyes más duras" (55\% del total de respuestas), mientras que en 2015, el cuidado de fronteras significó la preferencia del 27\%. Esa cifra ascendió no solo en el 2016 (32\%), sino también al año siguiente. En contraposición a esto, y en consonancia con lo que ocurrió en las intervenciones electorales de 2015, una medida de relevancia como "Políticas más eficientes antilavado de dinero" solo fue considerada en 2015 por el 14\% de los ciudadanos; en 2016, por el 11\%; y en 2017, por el 13\% (Universidad Argentina de la Empresa, 2017).
} 
Poner el foco en los inmigrantes a la hora de hablar de criminalidad y narcotráfico excede a las estrategias de comunicación de los candidatos en la Argentina contemporánea. Los inmigrantes regionales, especialmente de países limítrofes, han reemplazado a los inmigrantes europeos que llegaron al país a finales del siglo XIX y principios del XX como sujetos en cuestión respecto a temáticas que refieren a la inseguridad urbana y a la falta de trabajo. Así, durante los 90, la construcción de este relato xenófobo tuvo como eje principal la intervención del Gobierno argentino y los medios de comunicación, que buscaban un "chivo expiatorio" de la crisis económica y social que atravesaba el país y que se acentuaría en los años siguientes (Grimson, 2006). Pereira (2016) argumenta que el proceso de securitización de la inmigración en el país fue cobrando forma y contenido en las primeras décadas del siglo XX con la emergencia de la cuestión social y el anarquismo. El autor concluye que a partir de los discursos de las elites de la época y de las prácticas burocráticas y judiciales se fue legitimando un modo de comprender la inmigración como amenaza al orden social. Asimismo, otras investigaciones han abordado también el tratamiento de la migración en la comunicación política del Gobierno de Mauricio Macri en la ciudad de Buenos Aires (López, 2012; Mera y Vaccotti, 2013; Sznaider, 2015), lo cual marca la actualidad de la vinculación entre inmigración y ciertas cuestiones sociales de preocupación ciudadana en los discursos políticos durante los periodos de gestión pública.

La discusión sobre las fronteras se constituye como una preocupación central en nuestras proximidades, en nuestros barrios. ¿Es una problemática que se circunscribe a los territorios fronterizos? Los ciudadanos que residen en las áreas metropolitanas más grandes de la nación (Gran Buenos Aires, Gran Córdoba y Gran Rosario) están bien distanciados de los puntos fronterizos que mayormente son caracterizados como peligrosos y, sin embargo, los candidatos problematizan los márgenes nacionales como fuente de riesgos para todos los ciudadanos argentinos. ¿Cuándo los bordes nacionales fueron objeto de la agenda política electoral a nivel nacional? El contrabando, por ejemplo, ¿ha formado parte de las discursividades políticas presidenciales? La sensación de cercanía del fenómeno narco se constituye a partir de la discusión sobre los riesgos a nivel barrial. El peligro de las fronteras no solo hace referencia a los límites nacionales inseguros, también habla de las demarcaciones internas a nivel comunitario. Son varias las intervenciones discursivas de la campaña de 2015 que asociaron el espacio local con la posibilidad de convertirse en riesgosos: ambientes de infección proclives a la expansión de sus peligrosidades, barrios desprotegidos, territorios urbanos donde germinarían las condiciones para una criminalidad sin fin. Las imágenes electorales de gran parte del arco político en competencia reforzaron este imaginario.

El narcotráfico se habría guarecido en ámbitos íntimos y en sectores vulnerables: en las familias, en barrios pobres. Sergio Massa prometió la intervención de las Fuerzas 
Cristian Manchego Cárdenas

Luchar contra el narcotráfico: comunicación política electoral sobre las drogas ilícitas en Argentina

Armadas, con asistencia logística, en "barrios de Rosario y del Gran Buenos Aires, donde hoy, en lugar de mandar la policía, manda el capo que vende drogas" (Argentina Debate, 2015a). Así, la intervención en clave armada se conjuga bien con las retóricas políticas que caracterizan a determinados espacios urbanos como infectados por la narcocriminalidad. El campo político conoce los márgenes territoriales del crimen organizado y, por ende, los espacios donde el Estado tendría que actuar: territorios ausentes de la acción gubernamental, ámbitos copados por las redes de poder del enemigo que afectan a los más vulnerables. A nivel local, se discute la situación de los barrios pobres como principal foco de infección dentro del entramado urbano. Las representaciones audiovisuales que apuntan a intervenir en barrios pobres y villas de emergencia configuran sentidos estigmatizantes en torno a los sujetos que habitan aquellos ámbitos (Figura 3). Este modo de significación acerca de los territorios actualiza el vínculo ya desarrollado en algunos análisis sobre el campo político y los medios de comunicación: vulnerabilidad social, criminalidad y gestión del control social (Martini y Contursi, 2012; Sánchez, 2014).

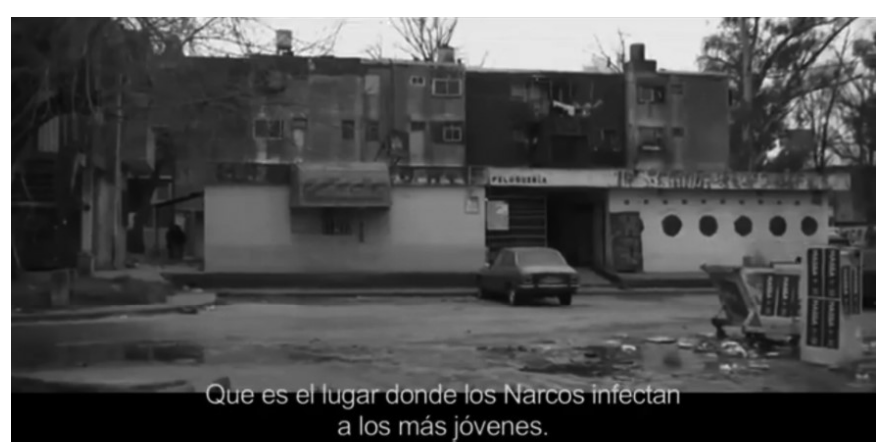

Figura 3. Spot de Unidos por Una Alternativa sobre seguridad ampliada. (Fuente: Observatorio Comunicación, Política y Seguridad, 2016a).

El comercial de Cambiemos "Erradicar el paco de toda la Argentina" (Figura 4) señalaba que "el paco afecta a los que menos tienen" (Mauricio Macri, 2015). Territorios vulnerables, el peligro como potencialidad. Calles angostas, caminos de trazos improvisados. ¿Quiénes viven en estos ámbitos? Sujetos-víctimas del sistema social y económico que los excluye. Ciudadanos-víctimas de la peor de las drogas. "Hay que atacar principalmente el tema del paco, que es el peor mal que está destruyendo nuestras familias" (Mauricio Macri, 2015), enfatizaba Mauricio Macri en el anuncio. Determinadas sustancias serían más riesgosas por circular en algunos territorios de la urbe. Son espacios urbanos desprotegidos, ausentes de la presencia del Estado. El consumo de drogas se devela como una problemática de índole familiar, íntima, desligada -en cierta forma, pero no definitivamente- del delito urbano. Criminalidad y pobreza, un vínculo poco novedoso en los discursos políticos y mediáticos. 
Austral Comunicación

Volumen 9, número 2 (Diciembre de 2020):481-518. ISSN 2313-9129

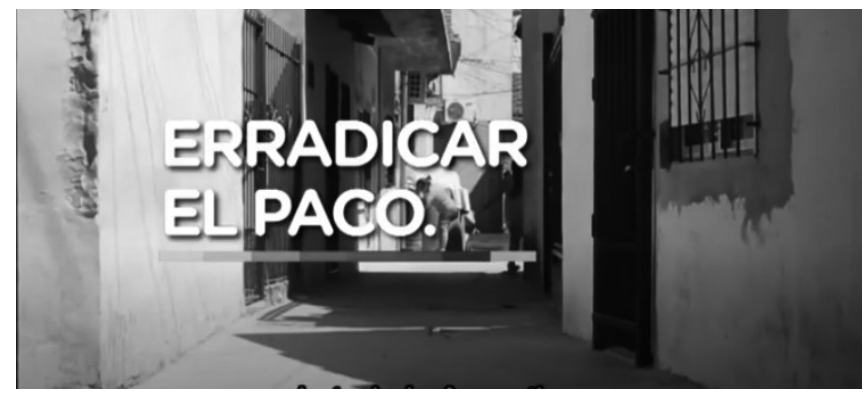

Figura 4. Spot de Cambiemos sobre la erradicación del paco. (Fuente: Mauricio Macri, 2015).

Las noticias sobre la inseguridad urbana refuerzan imágenes, sentidos e imaginarios estigmatizantes. Sánchez (2014) menciona que en las noticias sobre la criminalidad se dividen mundos de la urbe que son incluyentes y excluyentes, territorios del bien y del mal, de la legalidad y la ilegalidad. Estas operaciones se realizan junto con caracterizaciones sobre los sujetos que habitan estos espacios: quienes pueden llamarse "ciudadanos" con derechos y las clases peligrosas. La autora analiza los discursos sobre la inseguridad en la prensa gráfica hegemónica en Argentina a partir de los modos discursivos en los que los sujetos y los territorios son construidos por los medios. "La nominación construida es asignada a determinada franja etaria de las clases marginales y pone foco en reforzar una vinculación determinista entre el delito y la pobreza, que despoja a ambos fenómenos de su contexto de emergencia", lo que enfatiza "una vinculación unicausal entre pobreza y delincuencia” (Sánchez, 2014, pp. 144-145).

De acuerdo con parte del discurso político que analizamos, el narcotráfico gobierna no solo en los territorios urbanos que se encuentran en un extremo de las estructuras socioeconómicas, también actúa de manera activa en todos los niveles jerárquicos de clase social. Para algunos candidatos, intervenir en clave territorial implica visibilizar y problematizar espacios socioeconómicamente bien posicionados. Se apunta a discutir quiénes son y dónde viven los "verdaderos capos de la droga". ¿Acaso son quienes habitan en las villas? El planteo del candidato del Frente de Izquierda y de los Trabajadores seguía esta línea argumentativa. De aquí que la zona de Puerto Madero o barrios cerrados como Nordelta fueran caracterizados como centro de narcotraficantes. Para hablar del problema, no era necesario referirse a ámbitos pobres ni periféricos: "Los narcos están en Nordelta, en Puerto Madero" (Argentina Debate, 2015a), fueron las definiciones que dio Nicolás Del Caño durante el primer debate presidencial ante Sergio Massa, exintendente del partido de Tigre, municipio donde se ubica Nordelta.

Respecto a las representaciones del narcotráfico y su vinculación con sectores de alto poder adquisitivo, las series y novelas de ficción que abordan el fenómeno del nar- 
Cristian Manchego Cárdenas

Luchar contra el narcotráfico: comunicación política electoral sobre las drogas ilícitas en Argentina

cotráfico (producidas en países como Colombia, México y Estados Unidos y consumidas también por la audiencia argentina) configuran narrativas acerca de los ostentosos modos de vida de los miembros del crimen organizado, las particularidades de las mafias y su relación con el poder político de alto mando (Acosta Jiménez, 2013; Mizrahi et al., 2018). Las elecciones presidenciales de 2015 sucedieron luego del estreno de estas producciones audiovisuales en el país. De hecho, para ese año, los medios de comunicación ya habían abordado episodios noticiosos de capturas a capos del narcotráfico en sectores pudientes del país. Las historias protagonizadas por importantes cabecillas del negocio de las drogas que residían en la zona norte del Gran Buenos Aires se impregnaban en las pantallas televisivas de los ciudadanos.

Los candidatos presidenciales de 2015 pudieron diagramar, en clave adversativa, un modo de intervención discursiva que permitía valorar la experiencia de gestión pública del contrincante. En las enunciaciones políticas, la figura del futuro representante del Estado no podía estar investida de ineficacia. De aquí que los candidatos opositores al oficialismo advirtieran sobre los riesgos de la posible expansión y perdurabilidad de la problemática si continuaba la gestión de turno. “¿Cómo te sentirías de cómoda si quien tiene que resolver lo que está pasando es Aníbal Fernández?” (Argentina Debate, 2015a), ${ }^{10}$ le preguntó Mauricio Macri a Margarita Stolbizer (candidata de Progresistas) en el primer debate presidencial desarrollado en el auditorio de la Facultad de Derecho de la Universidad de Buenos Aires.

En campaña, el discurso político mapea los peligros de la urbe en función de cómo el adversario gestiona o gestionó la seguridad y el narcotráfico durante su administración. Intervenir en clave territorial implica configurar algunos espacios urbanos como riesgosos debido a la ineficacia de la práctica gubernamental llevada a cabo por el contrincante. "Crecen seis cocinas de paco por día en la Argentina y prácticamente la mitad son en el Gran Buenos Aires" (Argentina Debate, 2015b). En esta declaración de Mauricio Macri hacia Daniel Scioli realizada en el segundo debate presidencial se concreta la acción política en función de la gestión territorial. En el mismo evento de campaña, Daniel Scioli aludió que "95.000 policías es la mayor renovación cuantitativa y cualitativa de la historia de la Policía de la provincia de Buenos Aires" (Argentina Debate, 2015b). La experiencia de gobernabilidad en términos numéricos mostraba a un líder con capacidad de mando, quien concluyó con una pregunta para el candidato de Cambiemos: "Si todavía no pudiste resolver el problema de los trapitos [en la

\footnotetext{
${ }_{10}$ En agosto de 2015, en pleno contexto electoral, el periodista Jorge Lanata presentó en su programa PPT (Periodismo Para Todos) un informe televisivo que reforzaba el supuesto de la relación del entonces jefe de Gabinete, Aníbal Fernández, y el narcotráfico. En el libro Narcofugas (2016), la periodista Cecilia González menciona que el vínculo constantemente mediatizado de la figura de ese funcionario público y el negocio ilegal de las drogas tomó fuerza en 2008 con el caso conocido como "El triple crimen de la mafia de la efedrina", que asociaba el tráfico del precursor químico con los representantes del Gobierno y la financiación de la campaña electoral de 2011 de Cristina Fernández.
} 
Austral Comunicación

Volumen 9, número 2 (Diciembre de 2020):481-518. ISSN 2313-9129

Ciudad], ¿en serio creés que la gente va a creer que vos podés solucionar el problema del narcotráfico?" (Argentina Debate, 2015b). El territorio y sus peligrosidades no solo se constituyen como espacios inherentes a la narcocriminalidad, también son el campo de disputa por la definición de éxito o incapacidad de la gestión de la política securitaria de un determinado candidato. En estos casos, el peligro radica en la posible expansión de las peligrosidades locales a nivel nacional.

Los candidatos caracterizan los territorios usualmente como peligrosos y al sector oficialista como poco efectivo frente a la criminalidad. Entonces, gran parte del arco opositor le garantiza al electorado ser "el primer presidente" en darle batalla al narcotráfico. En este sentido, se propone recuperar lo no protegido por un Gobierno que, en lugar de enfrentar la problemática, niega su verdadera dimensión. "Vivimos en medio del avance de la droga y el Gobierno dice que somos un país de tránsito [en el tráfico de drogas]" (Argentina Debate, 2015a), mencionaba Sergio Massa en el primer debate presidencial. Si en algunos casos el éxito de gestión de un candidato en materia de seguridad pública en el plano local puede ser transferido al territorio nacional frente a una caracterización del contrincante como ineficiente, las alarmas de la posible expansión de desidia y ausencia del Estado son encendidas. El destinatario-víctima de las enunciaciones políticas cobra dimensiones totalizantes. Los ciudadanos perjudicados ya no serían solo quienes toleran el modo de gobernar la problemática en alguna localidad o provincia, sino los habitantes de todo el país.

En definitiva, el discurso político mapea a nivel nacional territorios con vínculos con la narcocriminalidad. Se describen ámbitos en los que el futuro Estado tendría que intervenir, en gran medida, de forma policial. Sergio Massa y Mauricio Macri fueron quienes priorizaron significaciones en torno a ámbitos económicamente vulnerables, villas de emergencia y barrios pobres, a partir de eufemismos como "los que menos tienen". En contraste con esta postura, pero en la misma línea argumentativa, Nicolás del Caño apuntó a sectores socioeconómicamente bien posicionados como focos del delito. En cualquiera de los casos, las representaciones espaciales en torno al narcotráfico son rasgos característicos del discurso político en competencia.

Si bien en el plano discursivo la problemática de las drogas se circunscribe a determinados ámbitos del país, en la enunciación política la figura del destinatario-víctima adquiere dimensiones totalizantes. El nosotros-nacional en riesgo tiene su correlato en un Estado ausente que no ha podido enfrentar al narcotráfico y, sobre todo, no ha mantenido en resguardo la soberanía del país. La causa de la cuestión narco deja de estar puertas adentro y pasa a ser de asunto externo, un problema que se ha filtrado por las fronteras nacionales. Así, una de las medidas más reclamadas para luchar contra el narcotráfico es la protección de las fronteras nacionales. 
Cristian Manchego Cárdenas

Luchar contra el narcotráfico: comunicación política electoral sobre las drogas ilícitas en Argentina

\section{Normas y castigo: intervención en clave legal}

Este apartado analiza cómo en los discursos políticos de 2015 se propuso intervenir ante el narcotráfico en función de la aplicación de los castigos desde un enfoque legal-normativo. Las definiciones en torno a la figura de la ley y a las modificaciones legales demandadas por los candidatos, así como las sanciones exigidas para el narcocriminal, fueron prioritarias en las discursividades electorales de esa campaña. Desde la apelación a la acción legislativa, los candidatos al Ejecutivo hicieron hincapié en la necesidad de más y mayores castigos. El umbral de tolerancia se franqueó y el Estado debía reaccionar y accionar contra el narcotráfico a través de la norma.

"Tolerancia cero con el narcotráfico. Es muy claro. Es orden, autoridad y legalidad. Esa es mi política de seguridad ciudadana" (Daniel Scioli, 2015). La legalidad de la cual hablaba el candidato Daniel Scioli en una entrevista realizada el 11 de noviembre de 2015 en A Dos Voces marca el tercer punto de una fórmula de éxito. Donde no hay orden, hay caos. El desorden sin acción política se entiende como un ámbito propicio para la reproducción del narcotráfico, la violencia, la delincuencia y otras problemáticas ligadas a la seguridad ciudadana. Un Gobierno involucrado con la problemática exige reformas en el Código Penal. En la enunciación política, el futuro representante del Estado es quien erige el andamiaje de la acción legislativa, el guardián de la norma y de sus reformas. Sergio Massa exponía con regularidad, en spots y entrevistas, que en su Gobierno los narcos y violadores tendrían cadena perpetua. De hecho, el candidato promovía una "profunda reforma del Código Penal y del Código Procesal" (Observatorio Comunicación, Política y Seguridad, 2016d). Por su parte, Nicolás del Caño militaba a favor de la despenalización del uso de la marihuana. El líder del Frente de Izquierda y de los Trabajadores instaba a rever las penalizaciones al consumo de determinadas sustancias. Así, cada candidato al sillón presidencial era portavoz de cualquier acción reglamentaria que pudiera promoverse. La figura de la ley condensa la preeminencia del campo político a la reforma legislativa como modo de enfrentar al crimen. El ideal punitivo es caracterizado a través de las proclamas para el incremento de los castigos y el efectivo cumplimiento de las leyes, en especial de las condenas definidas. El concepto de "ley" propuesto por el candidato Sergio Massa en los meses electorales refuerza este punto. El Estado, así, debe garantizar, ejecutar y modificar la legislación para castigar con mayor dureza a los involucrados en el negocio ilegal. Para vivir en paz y estar seguros es preciso que el Estado actúe en estos términos. "Tolerancia cero". La expresión es común entre los candidatos. Por ejemplo, para Sergio Massa, en el spot que prometía "prisión perpetua para narcos y violadores" (Observatorio Comunicación, Política y Seguridad, 2016d), y en su plataforma electoral, esa era la postura que el Gobierno venidero debía adoptar frente al enemigo. Desde ese lugar enunciativo similar se construye un diagnóstico común 
Austral Comunicación

Volumen 9, número 2 (Diciembre de 2020):481-518. ISSN 2313-9129

de "crisis de seguridad" (Foucault, 2006) como consecuencia del ilícito de las drogas. Las sanciones drásticas posicionan al candidato como conocedor del campo judicial, legislativo y penal.

Los candidatos presidenciales toman distancia de los argumentos que los presentan ante la ciudadanía como endebles frente al narcotráfico. Las promesas electorales cristalizan lo que debe hacerse y decirse como futuro representante de los argentinos. Sergio Massa exigía castigar al criminal con "todo el rigor de la ley". La eminencia de la norma da forma al discurso político. La ley cristaliza y evoca el marco de consensos que hemos desarrollado para vivir como ciudadanos democráticos. En algún punto, ese acuerdo había fallado: ya sea porque la pena era endeble o porque era desproporcionada frente a la magnitud del daño. Por ello, los "beneficios" para el victimario son inaceptables. El diagnóstico ampliamente compartido es que el Código Penal tiene un abordaje insuficiente para luchar contra la narcocriminalidad. "En la Argentina hay más personas con pedido de captura que detenidos. Esa es la realidad del sistema penal argentino" (C5N, 2015). Las instituciones encargadas del mantenimiento del orden público y de juzgar a los criminales no cumplen su tarea. En estos casos, la Justicia aparece como sujeto en las retóricas políticas.

"Puerta giratoria". Esta expresión -común en las discursividades de Sergio Massa y Mauricio Macri- deposita en jueces y fiscales parte de la responsabilidad de que los sujetos detenidos por narcotráfico no cumplan la pena que se merecen. El narcocriminal es la figura central a la que apunta este tipo de enunciaciones políticas, las cuales demandan que el Estado actúe en material legal. El presupuesto es que el delincuente obtiene beneficios punitivos a través de argucias ante el endeble sistema procesal penal. La norma aparece como relegada e incompetente debido a las artimañas del criminal. La ley sobre el narcotráfico y uso de drogas es arcaica, permisiva. "Diez años de condena van a ser diez años de cárcel", prometía el candidato Massa (C5N, 2015). Los tribunales e instituciones públicas que administran la Justicia tratan a los delincuentes con laxitud y acentúan los riesgos que enfrenta la ciudadanía. Ante la idea de que la ley es un modo de lucha contra el crimen que se configura como una extensión de la metáfora de la guerra contra el delito (Simon, 2011, p. 134), el campo político electoral pone en jaque al sistema judicial, penal y legislativo con el objetivo de plantear reformas punitivas que interpelen a los electores desprotegidos.

"Prisión perpetua para narcos y violadores" (Figura 5) formó parte de la intervención política en clave legislativa que focalizaba la necesidad de impartir penas "más duras" contra narcocriminales, merecedores del mismo castigo que los violadores, ultrajadores de destinos. ¿Quiénes son las víctimas de la droga? A grandes rasgos, niños y jóvenes, sujetos vulnerables a las redes del consumo. El futuro del país, en riesgo. 
Cristian Manchego Cárdenas

Luchar contra el narcotráfico: comunicación política electoral sobre las drogas ilícitas en Argentina

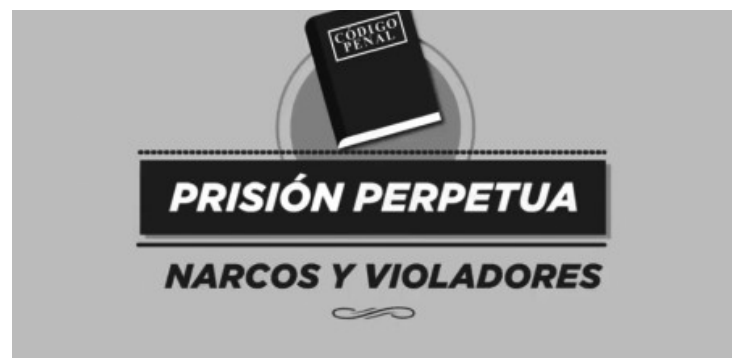

Figura 5. Spot de Unidos por Una Alternativa sobre la prisión perpetua para narcos y violadores. (Fuente: Observatorio Comunicación Política y Seguridad, 2016d).

En spots audiovisuales, el candidato Sergio Massa dejó en claro quiénes eran las víctimas del narcotráfico. El candidato recorrió barrios marginales, espacios propensos a la criminalidad. Niños y jóvenes, rostros de quienes serían los principales afectados por el narcotráfico acompañaban al candidato, que mostraba comprensión ante el panorama de crisis (Figura 6). La gravedad del daño y la posibilidad de esperanza que los rostros representan obligan a pensar sanciones drásticas. "Nadie puede no compartir la preocupación común que tenemos todos. Que es la contracara de la vida. Que destruye. Que mata..." (Daniel Scioli, 2015). Las palabras de Daniel Scioli en A Dos Voces diagnosticaron la gravedad de la problemática en el país. En contextos de emergencia, no solo los candidatos proponen y habilitan sensibilidades punitivas, también los periodistas debaten sobre la cuestión de las drogas. En los meses electorales de 2015, los candidatos tuvieron que construir respuestas sobre el narcotráfico para ir a tono con el discurso mediático. Por ejemplo, en las entrevistas televisadas que relevamos para este trabajo, hubo por parte de periodistas preguntas específicas sobre drogas ilícitas y modos de intervención estatal. El segmento de los debates presidenciales "Seguridad y derechos humanos", en el que hubo cuestiones puntuales acerca de la temática del narcotráfico, también encaja en esta línea de agenda mediática que impregnó la campaña de 2015.

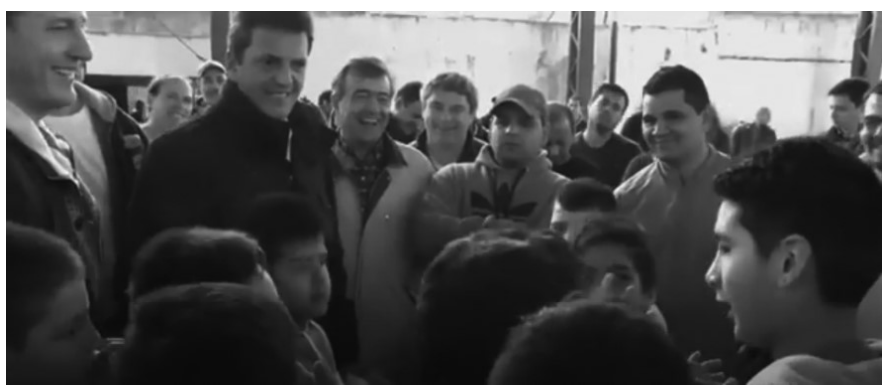

Figura 6. Spot de Unidos por Una Alternativa sobre seguridad ampliada. (Fuente: Observatorio Comunicación Política y Seguridad, 2016a). 
Austral Comunicación

Volumen 9, número 2 (Diciembre de 2020):481-518. ISSN 2313-9129

El candidato oficialista Daniel Scioli era visto por los candidatos opositores como representante del Estado ausente y, por ende, como responsable de la expansión del narcotráfico en el país. Frente a esto, era común que Scioli ratificara su autonomía respecto al Gobierno de turno. Por ello, el candidato mencionaba con regularidad que la gestión de la presidenta Cristina Fernández terminaría en la fecha estipulada por la Constitución Nacional, es decir, el 10 de diciembre de 2015. La consigna del Frente para la Victoria "Cambio con continuidad responsable" se utilizó con mayor regularidad después de la primera vuelta electoral y le otorgó sentido a la contraposición entre Daniel Scioli y Mauricio Macri respecto a las políticas económicas de cada proyecto político. Así, el primero se presentó como la opción del cambio responsable frente al segundo candidato.

La pena cumple con sopesar el daño causado: "El que tiene que ir preso, va a ir preso. Pero, además, vamos a un modelo de cárceles fábrica" (C5N, 2015), proponía Sergio Massa. El sufrimiento merecido del culpable es justo. En escenarios de emergencia, para enmendar el miedo y los riesgos de la presencia de la droga en el país, se requiere modificar la ley. La rigurosidad de la condena, sin beneficios procesales, implicaría que los criminales en potencia reflexionen sobre las consecuencias de sus acciones futuras. Se trata de un sujeto racional capaz de realizar cálculos de costo-beneficio. Asimismo, se trata también de un sistema penal racional: cárceles fábrica en beneficio de un Estado que determina que el delincuente pague por sus acciones a la sociedad victimizada.

En los discursos políticos electorales, la ley y el castigo aparecen como desactualizados respecto a la realidad desbordada de actos criminales. "Nuestro catálogo contemporáneo de 'monstruos', como los delincuentes sexuales, los integrantes de bandas delictivas, los jefes del narcotráfico y los delincuentes violentos reincidentes proporciona una base en permanente renovación para la acción legislativa" (Simon, 2011, p. 111). La práctica legislativa ha construido históricamente lo que hoy en día conocemos como el delito del comercio ilegal de drogas. En la década del 20, por ejemplo, la política argentina tomó nota de las intervenciones prohibicionistas a nivel internacional y pasó a establecer penas a través del Código Penal a quienes comercializaran sustancias sin autorización o sin prescripción médica. El problema del orden y la conservación de la vida es una perturbación intrínseca al Estado moderno en general y a las grandes urbes en particular. Lila Caimari (2012) menciona con respecto a la Buenos Aires de 1920-1945 que estos aspectos se profundizaron a medida que se acentuó la crisis económica, el incremento de la violencia en las calles y los reclamos de la sociedad civil. La demanda de orden por parte de la población al campo político fue conformando líneas de acción para intervenir frente a la preocupación social. La instauración de los edictos contravencionales de 1932 habilitó la imposición de una "ley policial" al fun- 
Cristian Manchego Cárdenas

Luchar contra el narcotráfico: comunicación política electoral sobre las drogas ilícitas en Argentina

cionamiento político, mientras que la emergencia vecinal de la época fue alimentada por discursos periodísticos que relataban sobre el delincuente y el desocupado.

Luchar contra el narcotráfico implica construir la figura de Estado presente que interviene legalmente en la producción, la circulación y el consumo de sustancias. Intervenir en clave legal significa también cuestionar las leyes prohibitivas sobre el uso de narcóticos específicos. Desde aquí se discuten las normas que criminalizan la tenencia de drogas para uso personal. Este abordaje no conlleva a una problematización acerca de los riesgos del consumo de sustancia para la criminalidad y la violencia urbana. La adhesión del frente de izquierda a la despenalización del uso de marihuana es un ejemplo claro de este modo de intervenir en clave legal. En este sentido, siguiendo a Cunial (2015), se observa que si bien han prevalecido miradas que conciben al uso de drogas como un delito y/o una enfermedad, frente al fracaso de la guerra contra las drogas se han promovido posturas políticas en el ámbito legislativo que proponen percibir el uso de estupefacientes como un asunto de autonomía y derechos humanos. Sin embargo, durante la campaña presidencial de 2015, esta no fue una arista temática de relevancia en gran parte del arco político en competencia.

La postura de legalizar lo ilegal revela algunas cuestiones importantes sobre el modo de significación de la lucha contra el narcotráfico. El fracaso de las actuales acciones represivas y estigmatizantes contra el delito son también foco de debate en el discurso político. La estrategia punitiva viciada en más policías y mayores castigos no habría servido de mucho en los últimos años. Margarita Stolbizer lo dejó en claro en el primer debate presidencial, en el que expuso la incongruencia de tener al Gran Buenos Aires "lleno de policías" y con cárceles "llenas de presos" si el delito continuaba cobrándose víctimas. Si bien el diagnóstico de la candidata apuntaba principalmente a Daniel Scioli, también se refería a las políticas fallidas que gran parte del arco político proponía como metodología de combate. "Hace tiempo que venimos escuchando las propuestas repetidas y ya fracasadas en la mayoría de los candidatos" (Argentina Debate, 2015a). Las políticas son cuestionadas y la gestión del delito por parte del Estado se torna incompetente. La lucha contra el narcotráfico abarca un amplio abanico de discursos posibles. No se trata de posicionamientos contrapuestos del todo. Mientras que Sergio Massa pedía una reforma integral del Código Penal y exigía cadena perpetua para narcotraficantes, Nicolás del Caño demandaba la despenalización del consumo de marihuana. En los discursos políticos, en gran medida, la figura de la ley cristaliza un espíritu latente de modernidad. La norma aparece como desactualizada con respecto al avance de las actividades catalogadas como delito. El candidato de Compromiso Federal lo expuso de mejor forma. Rodríguez Saá dio un guiño de adhesión a medidas que implicaban la legalización de ciertas drogas o nuevos modos de abordar la lucha contra el narcotráfico. "Hay que mirar el ejemplo uruguayo; seguir con mucha atención 
qué ocurre en el Uruguay con la política muy moderna que han implementado al respecto", exponía en el debate presidencial (Argentina Debate, 2015a). En general, existe una referencia a que la ley tendría que ajustarse a los nuevos tiempos. Sin embargo, resulta llamativo que, en el mismo debate presidencial, Rodríguez Saá haya demandado el cuidado de las fronteras con la Gendarmería como modalidad de intervención estatal y que después haya instado a pensar en políticas "modernas".

El discurso político electoral sobre el narcotráfico habilita las adopciones de medidas excepcionales en un contexto de emergencia. El debate entre los candidatos durante la elección de 2015 acerca del derribo de aviones como medida de defensa territorial ejemplifica la configuración de un Estado de excepción. En los últimos años, es cada vez más recurrente en las democracias latinoamericanas la apelación al narcotráfico como un puntapié que acompaña la puesta en marcha de la figura de necesidad que implica el estado de excepción en clave agambeniana. Las medidas "se presentan así como una disposición -'ilegal' pero perfectamente 'jurídica constitucional' que se concreta en la producción de nuevas normas” (Agamben, 2004, p. 65). “¿Están en contra o a favor de la reforma del Código Penal, total o parcial?", fue una de las preguntas que planteó el periodista Luis Novaresio en el primer debate presidencial (Argentina Debate, 2015a). El campo periodístico toma en cuenta la relevancia de la problemática del uso y tráfico de drogas ilícitas e invoca a que el campo político dé respuestas a problemáticas ciudadanas. Los candidatos deben responder si estarían dispuestos a impulsar modificaciones no solo en el uso de las fuerzas de seguridad, sino también en materia legal. Esta situación no está alejada de lo que Cohen (2002) plantea en relación con cómo los medios de comunicación juegan un rol central en la construcción social de pánico moral y contribuyen a ampliar los márgenes de discrecionalidad de las agencias penales y a legitimar políticas de gestión de la exclusión. Los debates electorales acerca de "lo que hay que cambiar" en la legislación nacional para permitir el uso de las Fuerzas Armadas en la lucha contra el narcotráfico en las fronteras nacionales y en los "barrios más pobres" permite observar cómo la expresión de necesidad pone el acento en la modificación de la norma. La norma desactualizada deviene en instauración de una medida ilegal, pero necesaria. La imposición de sanciones, de castigos y el cuestionamiento a legislaciones que castigan el uso de sustancias dan cuenta del modo en el que el discurso político aborda la cuestión de las drogas en clave legal. A través de la figura del Estado legislador se busca restituir el imaginario de un Estado garante del orden público.

\section{Víctimas y victimarios del narcotráfico}

La intervención política respecto al tema del narcotráfico apela a la ciudadanía en términos de víctima: ciudadanos-víctimas del delito y violencia urbana ligados 
Cristian Manchego Cárdenas

Luchar contra el narcotráfico: comunicación política electoral sobre las drogas ilícitas en Argentina

al consumo de drogas, víctimas del entonces Gobierno ineficiente frente al combate contra el narcotráfico. Asimismo, ciudadanos-víctimas de las normativas punitivas, de las prácticas policiales represivas contra el uso de determinadas sustancias ilícitas y también adictos-víctimas de la desprotección del Estado en materia de salud pública. En la enunciación de Cambiemos, la figura de la víctima representa a niños, madres y adultos mayores de barrios afectados por la droga. Así sucede, por ejemplo, en el audiovisual “Terminar con el narcotráfico" (Mauricio Macri, 2015) (Figura 7).

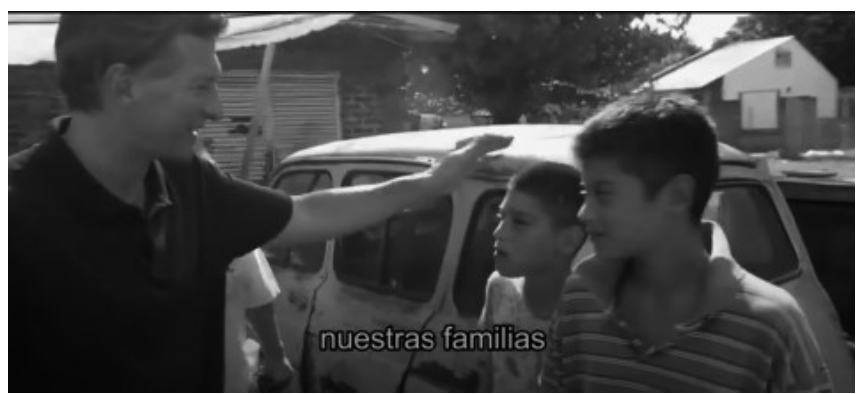

Figura 7. Spot de Cambiemos sobre la lucha contra el narcotráfico. (Fuente: Mauricio Macri, 2015).

En este caso, las escenas se representan en espacios en los que las familias, los vecinos y el ciudadano tienen relevancia. La enunciación política de Mauricio Macri describe a los ciudadanos-víctimas sometidos a "convivir a diario" con la presencia del narcotráfico en sus cercanías. Se trata de sujetos vulnerables, carentes de protección estatal. No obstante, la figura de la víctima que construye la fuerza política también representa a una ciudadanía activa. Además de rostros de preocupación, de incertidumbre, se muestra a sujetos que exigen soluciones y le demandan atención al candidato. Las imágenes políticas representadas por Cambiemos refieren a lo que Dagatti (2018) denomina "estética del costumbrismo aspiracional". Esta noción implica una exaltación de valores que pueden coincidir con los de la época romántica: el trabajo, el esfuerzo, la construcción eufórica de los sectores populares; son valores que tienen una dimensión más privada que pública, más individual que colectiva: se trata de cada trabajador, de cada familia, de cada vecino. Como en gran parte de las enunciaciones políticas, el pedido de la víctima es recuperado y explicitado por el candidato, que se involucra con el reclamo social.

Los candidatos tienen que mostrar efectividad y preocupación por las problemáticas que aquejan a la ciudadanía. 11 "Quien hable en nombre de las víctimas habla en nombre

${ }^{11}$ El informe de 2015 del Barómetro del Narcotráfico en Argentina, elaborado por la Universidad Católica Argentina (2016), muestra la evolución de la venta de droga en los barrios. En 2010, el 30,2\% de los ciudadanos consideraba que en su barrio se comercializaban drogas ilegales. En 2015, la cifra ascendió a 46,8\%, es decir, casi 5 de cada 10 hogares identificaban la venta o tráfico de drogas en su calle, manzana o vecindario. 
Austral Comunicación

Volumen 9, número 2 (Diciembre de 2020):481-518. ISSN 2313-9129

de todos nosotros" (Garland, 2005, p. 47). En el material de campaña que revisamos, las víctimas no hablan. Sus figuras pueden usarse en los spots audiovisuales, pero sus reclamos y sus voces son recuperados por el candidato. En las noticias mediáticas sobre inseguridad, la voz y testimonio de las víctimas frente a cámaras tiene gran relevancia en las demandas de seguridad (Calzado, 2015). Frente a esto, en épocas de campaña, el discurso político es portavoz de los reclamos sociales. El conflicto se narra a través de voces políticas, gestores de la acción pública. De aquí que en las enunciaciones políticas se construya una cercanía entre la figura del candidato y el destinatario a partir del uso del "nosotros" y del nosotros inclusivo. Se trata de un colectivo de identificación con riesgos y peligrosidades compartidas en el cual el enunciador y el enunciatario coexisten.

Esta significación se conjuga bien con las retóricas en clave adversativa (Verón, 1996). El discurso político de la campaña que analizamos apunta contra el modelo de gobierno kirchnerista respecto al tráfico de drogas. La figura del victimario se despliega entre el narcocriminal y los agentes encargados de la gestión del delito. En este punto, el significante de la corrupción aglutina el vínculo entre narcotráfico y Estado. Para vencer al narcotráfico, se hace necesario enfrentar la corrupción. En épocas electorales, los ciudadanos-víctimas de la ineficacia del Estado y del ocultamiento del crimen organizado son interpelados por los discursos políticos ávidos de venganza. Como menciona Simon (2011, p. 55), para la realidad estadounidense "el mandatario de estilo acusatorio" es el modelo de liderazgo en el poder ejecutivo. De aquí que candidatos y mandatarios se muestren identificados con la experiencia de la victimización delictiva y con el deseo de venganza que provoca. El temor a ser víctimas constituye un imperativo en las retóricas electorales de los candidatos presidenciales de 2015. La interpelación individualizada al destinatario remarca la idea de que cualquiera puede ser afectado por el narcotráfico. La figura de la víctima no solo convoca a sujetos-víctimas de hechos específicos, sino también a quienes potencialmente pueden y temen serlo. Así, los discursos de 2015 recuperan la retórica de la victimización (Pitch, 2009) sobre la efectivización del crimen en todas partes.

No hay situaciones de riesgo que los ciudadanos puedan sencillamente evadir. Víctimas de la violencia urbana exponencial a causa de la presencia de las drogas. Jueces y fuerzas policiales coludidos con la narcocriminalidad; políticos vinculados con el dinero del delito; familias-víctimas y jóvenes adictos. Los perjuicios del narcotráfico impactan en diversos ámbitos. En los discursos que analizamos, los ciudadanos-víctimas no son responsabilizados por la prevención del delito. No hay alternativa para que la ciudadanía construya una red de acciones que busque evadir la narcocriminalidad. La droga está en todos lados, como refería el candidato Mauricio Macri en uno de sus anuncios: "La droga ha ingresado en las familias, está en las calles y ha copado las instituciones" (Mauricio Macri, 2015). 
Cristian Manchego Cárdenas

Luchar contra el narcotráfico: comunicación política electoral sobre las drogas ilícitas en Argentina

En el discurso político, las demarcaciones de la figura de la víctima del narcotráfico varían según la perspectiva desde la cual se intervenga. "El problema de la droga hay que abordarlo desde dos puntos de vista. El adicto es un enfermo, es un tema de salud pública", mencionaba Daniel Scioli durante una conferencia de prensa en la ciudad de Rosario (Televisión Pública, 2015). Y agregó, bajo la mirada atenta del entonces secretario de Seguridad, Sergio Berni: "El narcotraficante es un criminal, es un tema de seguridad pública. Y ahí hay que caerle con toda la fuerza de la ley y todo el rigor de la fuerza de seguridad" (Televisión Pública, 2015). Como sucede en gran parte de la enunciación política en campaña, la categoría de víctima se amplía y se integra a la figura del adicto: toxicómanos, víctimas de la expansión y circulación de las drogas ilícitas en el país y de la desprotección del Estado en materia de salud pública. Este modo de significación de la figura de la víctima engrana con el eje joven-pobre-delincuente-drogadicto (Guemureman, 2014). En este sentido, si la discusión sobre el narcotráfico pasa por el tamiz de violencia-delito-seguridad, la figura del victimizador se asienta sobre el joven-pobre. Por el contrario, si el tópico de las drogas pasa por el filtro de la problematización de las políticas de salud pública, pobreza y marginalidad, el joven es configurado como víctima. Estas relaciones, por supuesto, no se dan de forma diferenciada en los discursos políticos, son transversales al modo de significación de la lucha contra el narcotráfico sobre las figuras de la víctima y del victimario.

Manzano (2014) señala que en la década del 60, a diferencia de otros países donde la construcción del toxicómano ha sido crucial para "dramatizar estereotipos raciales", posibilitando el control estatal sobre poblaciones no blancas, en la Argentina de la segunda mitad del siglo XX, la figura del adicto estuvo "menos asociada con las minorías étnicas o sexuales que con una categoría sociocultural basada en la edad, es decir, la juventud" (p. 53). Este vínculo entre seguridad interior y narcotráfico habilitó la definición del enemigo interno. Así, el "problema de las drogas" emergió en estrecha vinculación con las doctrina de la seguridad nacional, convirtiéndose en un eje central de intervención cultural y política durante la última dictadura militar desde el cual se generaron figuras alrededor de una juventud hedonista y de una familia desordenada, cuyos resultados principales se materializaron en "la subversión" que el Estado autoritario debía enfrentar.

En la campaña presidencial, la perversión de la futura generación del país es temida y alertada por la clase política. Jóvenes-víctimas, pero también posibles criminales. Frente a esto, se propone desenvolver un trabajo de prevención. Jóvenes-víctimas de la injusticia social, de la pobreza, de la falta de oportunidades. El negocio del delito del tráfico de drogas puede convertirse en una alternativa de vida para ellos. "[...] entrar en los barrios más humildes, que es el lugar donde los narcos infectan a los más jóvenes" (Observatorio Comunicación, Política y Seguridad, 2016a), mencionaba 
Austral Comunicación

Volumen 9, número 2 (Diciembre de 2020):481-518. ISSN 2313-9129

Sergio Massa en una de sus propagandas. Según la condición social, ciertos individuos son más vulnerables a ser absorbidos por las redes del narcotráfico. Los potenciales victimarios eran definidos a partir de sus virtuales acciones y no por sus actos concretos: juventudes amenazantes. Los jóvenes como victimarios potenciales también aparecen en el discurso mediático. Según Koziner (2014), la expresión “jóvenes en peligro" es utilizada por los medios de comunicación para tratar situaciones que involucran a estos actores con hechos de inseguridad y vulnerabilidad social.

La figura local del adicto como uno de los estereotipos del enemigo interno se moldeó a partir del accionar del Estado entre las décadas del 80 y del 90 . Parte de este proceso tuvo que ver con la retroalimentación entre los discursos médicos y policiales alrededor de los usuarios de drogas ilegales. A través de la elaboración de entrevistas a informantes clave y el estudio de fuentes documentales, Aureano (1998) describe cómo el Estado argentino criminalizó y estigmatizó a usuarios de estupefacientes ilícitos. En esta línea, Kornblit (2004) observa que, por lo general, se ha concebido el uso de drogas desde las siguientes lógicas no contrapuestas: la que involucra la "cura" para los usuarios (la lógica sanitaria) y la que busca el "control” (lógica punitiva), por lo que se consolida el binomio enfermedad-delito al momento de abordar estos temas. Así, la autora señala que en función de los términos "adicción”, "dependencia” y "abuso" se ha tejido una trama de prácticas discursivas e institucionales de muy diversos tipos (preventivas, epidemiológicas, forenses, terapéuticas) que prometen a cada usuario un mismo destino, signado por el descontrol y la marginalidad. Del mismo modo, se resalta el carácter inherentemente político que tiene esta clasificación: la delimitación de una sustancia como droga legal o ilegal responde a criterios arbitrarios por parte de las autoridades del sistema de fiscalización internacional (Aureano, 2004).

La plataforma electoral de Progresistas prometía expandir "la red de centros de tratamiento de adicciones para sacar a los jóvenes en situación de dependencia a sustancias psicoactivas, como el paco, un elemento clave en la reincidencia en los circuitos delictivos". Esto no solo refuerza el vínculo entre delito urbano y consumo de estupefacientes, también remarca este doble enfoque al respecto de la juventud y el narcotráfico: víctimas, pero también victimarios. A pesar de este planteo en clave de salud pública que visualiza a la víctima-adicta, gran parte del discurso político focaliza y acentúa las sanciones hacia los criminales en la línea de un Estado fuerte.

La figura del victimario ocupa un lugar abstracto en el que no se define con claridad quién es el enemigo a enfrentar. Narcotraficantes, jueces corruptos, policías cómplices, políticos de altos mandos, funcionarios del Gobierno, jóvenes consumidores; una amplia gama de actores intervienen en la consolidación de un escenario de anomia generalizada en el que es difícil ubicar a responsables específicos. La centralidad se coloca en un victimario peligroso, fantasmal y, en alguna medida, omnipresente: el narcotra- 
Cristian Manchego Cárdenas

Luchar contra el narcotráfico: comunicación política electoral sobre las drogas ilícitas en Argentina

ficante. A través de la corrupción, se aglutina de alguna forma la figura del victimario omnipresente. Las víctimas de la narcocriminalidad serían en realidad víctimas de un sistema corrupto. Los jóvenes, en lugar de ser vistos como potencial peligro para la sociedad, son visibilizados como víctimas de políticas criminalizantes y fraudulentas. "El pequeño delito al que son condenados sectores de la juventud es garantizado por las mafias policiales" (Argentina Debate, 2015a), explicaba Nicolás Del Caño en el primer debate presidencial. El candidato apuntaba a las políticas represivas en materia securitaria y al contubernio entre las fuerzas de seguridad y la criminalidad organizada. Las instituciones encargadas de gestionar el delito serían las que, en realidad, lo organizan. La causa del delito del tráfico de drogas se centraría en la mafia de los funcionarios públicos. Se trata de la configuración de una "víctima" que se diferencia de la mirada hegemónica. En los últimos años, la tematización del delito como inseguridad se delineó con un staff mediático permanente: las víctimas (Calzado y Van Den Dooren, 2009). Este concepto de víctimas se asocia a la idea del ciudadano-medio, tantas veces identificado con el apelativo "vecino", que se constituyó como el destinatario privilegiado de las discursividades de campaña de los partidos de centro y centro-derecha. El Frente de Izquierda, por el contrario, en su argumentación puso a los trabajadores en el rol de víctimas, no ya del delito callejero, sino de las maniobras estatales y de la corrupción de las fuerzas policiales (Calzado, Fernández y Lio, 2014b).

En la convivencia de las cúpulas policiales, judiciales e incluso políticas con este tipo de delito, el Estado aparece como el principal responsable de la situación. La comercialización de drogas sería una consecuencia de cadenas de asociaciones ilegales vinculadas con el Estado. Narcotráfico y corrupción se asocian, a la vez que se refuerzan uno al otro. Sin corrupción, para estas posturas, no habría narcotráfico; y para "enfrentar al narcotráfico" habría que "erradicar" la corrupción. De allí que el modo de construir la imagen del Estado corrupto se despliegue en gran medida a través del peligro de un delito organizado como lo sería la producción, distribución y venta de estupefacientes. Los candidatos priorizaron hablar de corrupción y narcotráfico en los debates presidenciales. Las referencias también estuvieron presentes en el material de campaña de las fuerzas políticas, pero el espacio de discusión en vivo entre los candidatos fue el privilegiado para el tratamiento de la temática. Desde Progresistas, Margarita Stolbizer trabajó su campaña en la línea de interpretación que relaciona corrupción, seguridad y narcotráfico. "No vamos a tener seguridad si no eliminamos la corrupción", mencionaba la candidata en el primer debate presidencial (Argentina Debate, 2015a). "El problema no lo tenemos en las fronteras, como muchos plantean. Lo tenemos delante de nuestras narices. Lo tenemos en Ezeiza, en Puerto Madero, en el río Paraná" (Argentina Debate, 2015a). Quienes deben controlar el territorio interno -las fuerzas policiales- y los encargados de vigilar los márgenes territoriales -los fun- 
Austral Comunicación

Volumen 9, número 2 (Diciembre de 2020):481-518. ISSN 2313-9129

cionarios de la aduana y aeropuertos- serían los responsables de la proliferación del narcotráfico. “¿Por qué pasa que aviones y barcos salen [con droga] de la Argentina?”. Estado ausente es igual a Estado permisivo, cómplice. "No hubo un Gobierno en la historia que haya tenido tantos funcionarios involucrados con la droga" (Argentina Debate, 2015a), continuaba la candidata en el debate. A fin de diferenciarse de los argumentos de sus contrincantes, Stolbizer problematizó el rol de un amplio abanico de actores involucrados con el delito. La relación entre drogas y corrupción se establece como amenaza. A su vez, la complicidad entre el crimen organizado y los funcionarios públicos pone en duda la efectividad de las Fuerzas Armadas como modalidad de combate contra el narcotráfico.

Corrupción y crimen organizado se relacionan a partir de la identificación de ciertos actores del Estado corrupto y sus lazos con la delincuencia organizada. Desde las retóricas electorales, esta operación focaliza determinados responsables: agentes de las fuerzas policiales y la Gendarmería, responsables en áreas fronterizas y funcionarios públicos pertenecientes al partido oficialista. Aunque con grandes salvedades en el tratamiento del consumo y tráfico de drogas en comparación con los otros candidatos, Nicolás Del Caño también identificó a las fuerzas policiales junto con un sector del Poder Judicial como actores relevantes dentro de la entramada red del crimen organizado. Durante el debate presidencial del domingo 4 de octubre de 2015, el candidato del Frente de Izquierda y de los Trabajadores explicaba: "Son las fuerzas policiales las que organizan el gran delito en complicidad con el sector judicial y el poder político" (Argentina Debate, 2015a). Los dispositivos de seguridad carecen de posibilidad de gobernar el narcotráfico: impunidad. El Estado sería incapaz de intervenir ante la crisis como producto de su fracaso en la protección de los ciudadanos. Los vínculos institucionales con el delito en las retóricas electorales exigen indignación, clamor de castigo.

"Resolver" la cuestión de las drogas a partir del fortalecimiento de las fuerzas en clave cuantitativa y cualitativa no fue una estrategia que Nicolás Del Caño haya priorizado. Sin embargo, el candidato no pudo esquivar el tratamiento de un tópico de relevancia en la campaña. La agenda temática del rol de las fuerzas de seguridad y armadas marcó la orientación del debate. En efecto, la izquierda también debió incorporar los tópicos de la criminalidad dentro de su agenda electoral, algo que históricamente solía estar alejado de su programa de gobierno. La pregnancia en la opinión pública y en el espacio político del tópico del narcotráfico y la corrupción hizo que todos los actores políticos, incluso los más alejados, tuvieran que incluir diagnósticos e intervenciones en sus agendas y mostrar desde allí las diferencias frente a otros espacios políticos. En el análisis de los discursos de campaña de Margarita Stolbizer y de Nicolás del Caño se identifica que ambos candidatos describen actores específicos dentro de las estructuras del Estado, sin los cuales el crimen organizado no podría actuar en el país. A diferencia 
Cristian Manchego Cárdenas

Luchar contra el narcotráfico: comunicación política electoral sobre las drogas ilícitas en Argentina

de estos, en las discursividades de Sergio Massa y de Mauricio Macri prevalecen las abstracciones a partir de la figura de un enemigo omnipotente, sin describir actores específicos.

En definitiva, las definiciones del discurso político en torno a la figura de la víctima del narcotráfico no se limita apenas a los riesgos de carácter securitario, abarca también una ciudadanía enfrentada a la incapacidad del Estado de manejar un proyecto antinarcóticos. El temor a ser víctimas constituye un imperativo en las retóricas electorales. La interpelación individualizada al destinatario en la que se remarca la idea de que cualquiera puede ser afectado por las peligrosidades del narcotráfico tiene su correlato en jóvenes y familias de barrios vulnerables como principales víctimas. A su vez, en la enunciación política, la categoría de la víctima se amplía y se integra a la figura del adicto. La figura del victimario ocupa un lugar abstracto en el que no se define con claridad quién es el enemigo a enfrentar. La centralidad se coloca en un victimario peligroso, fantasmal y, en alguna medida, omnipresente: el narcotraficante y sus vínculos con el sistema judicial, penal y político. La corrupción (pública) aglutina de alguna forma las significaciones que giran en torno al victimario. En este sentido, hablar de lucha contra el narcotráfico también implica discutir acerca de la corrupción.

\section{Conclusiones}

La lucha contra el narcotráfico ha ocupado el centro de la agenda política de muchos países de la región y ha implicado la puesta en marcha de una serie de respuestas securitarias que incluyen el uso de las Fuerzas Armadas. La estrategia militarista y policial, además de haber resultado inefectiva en el propósito de acabar con el narcotráfico, ha profundizado los niveles de violencia en naciones como México, Colombia y Brasil. Teniendo en cuenta este contexto y el análisis desarrollado en el presente artículo, entendemos que el tratamiento del narcotráfico por parte de los candidatos presidenciales de 2015 en la Argentina no generó un debate alternativo al enfoque prohibicionista y punitivista de las drogas ilícitas que permitiera enriquecer la dimensión significante y perceptiva de los ciudadanos en torno al tema.

En los discursos que analizamos, luchar contra el narcotráfico significó poner en la escena política la figura de un Estado ausente. Las retóricas en clave adversativa atravesaron los discursos que construyeron como prodestinatario (Verón, 1996) a la ciudadanía víctima de la criminalidad y vulnerabilidad debido al proclamado avance de las drogas en el país. De hecho, la hipótesis que asumimos tiene como fundamento una matriz adversativa, ya que si bien las cuatro líneas discursivas planteadas son transversales a las comunicaciones de las fuerzas políticas en competencia, se diferencian principalmente en función de la ubicación que ocupe el enunciador político, ya sea el oficialismo o la oposición al Gobierno de turno. 
No podemos afirmar que los hallazgos del presente estudio fueran particularmente exclusivos de la campaña de 2015. El desarrollo de investigaciones que aborden el objeto en su desenvolvimiento histórico nos ayudará a dilucidar más el panorama. Sin embargo, podemos concluir que es cuestionable cualquier hipótesis que deslice la idea de que una determinada fuerza política -o candidato específico- que haya trabajado enfáticamente el tema en aquellos meses electorales haya iniciado la discusión de la cuestión de las drogas ilícitas en el país. Si los candidatos presidenciales trataron en mayor o menor medida el tema en sus piezas comunicacionales, se explica más en función del modo en el que se presentaron estratégicamente.

El vínculo impulsado mediáticamente entre algunos funcionarios públicos del entonces Gobierno y el negocio del narcotráfico, y algunos resultados de estudios tanto de opinión pública como de agenda mediática en los que se muestra la repercusión pública del narcotráfico, dan cuenta de los rasgos particulares del escenario político-social de 2015. No es posible afirmar que el discurso político sobre el narcotráfico haya surgido bajo la determinación de estas variables. No obstante, haber señalado estos elementos contextuales a lo largo de esta investigación posibilita comprender la relevancia que tuvo el narcotráfico en la agenda pública de 2015.

La figura de Estado ausente en el discurso político fue representada por el Gobierno kirchnerista. En el análisis, hemos descrito cómo incluso el candidato oficialista, Daniel Scioli, intentó desapegarse de la figura continuista de Cristina Fernández y reconoció la importancia de que el Gobierno venidero enfrentara al narcotráfico. En este sentido, los discursos políticos construyeron la figura del futuro presidente del país a partir de cualidades tales como la eficiencia, la capacidad de acción y, sobre todo, la experiencia en cargos de gestión política. Los principales candidatos, Daniel Scioli, Mauricio Macri y Sergio Massa, se volcaron a visibilizar las políticas en materia de seguridad que habían implementado durante sus respectivos mandatos municipales o provinciales.

Para combatir el narcotráfico se requirió la conformación de un Estado con mano dura a partir de la utilización de las Fuerzas Armadas y la profesionalización de las fuerzas de seguridad. Este abordaje catalizó líneas argumentativas que, con variantes y claroscuros particulares, quedaron circunscritas al rol del brazo armado del Estado como modo de combate. Por ello, incluso el candidato de izquierda, Nicolás del Caño, a pesar de no construir un plan programático policial, abordó la propuesta represiva, aunque centrándose en sus aspectos negativos. Por momentos, el debate se redujo a la utilización o no de las Fuerzas Armadas, con lo cual se restringió una discusión superadora, imaginativa y realista en torno a los modos de enfrentar a la criminalidad organizada, más allá de la despenalización del uso de sustancias. Sea como fuere, el rol de las fuerzas de seguridad y de las Fuerzas Armadas se consolidó como eje central del debate electoral. En este sentido, lejos de adoptar un discurso que los presentara como 
Cristian Manchego Cárdenas

Luchar contra el narcotráfico: comunicación política electoral sobre las drogas ilícitas en Argentina

endebles ante la ciudadanía, gran parte de los candidatos acentuó el uso de retóricas punitivas y priorizó su experiencia en gestión securitaria.

Luchar contra el narcotráfico significó cuidar los territorios nacionales caracterizados como peligrosos a causa de la droga: fronteras nacionales y espacios urbanos pobres. Si bien la problemática de las drogas se circunscribió a determinados ámbitos del país, la figura del destinatario-víctima adquirió dimensiones totalizantes: el nosotros-nacional en riesgo tuvo su correlato en un entonces Estado ausente que no pudo enfrentar al narcotráfico y, sobre todo, no mantuvo en resguardo la soberanía del país. El discurso político mapeó a nivel nacional territorios con vínculos con la narcocriminalidad y describió ámbitos en los que el futuro Estado tendría que intervenir, en gran medida, de forma policial.

Intervenir en clave legal dio cuenta del modo en el que el discurso político significó, a través del uso de la ley, el combate a las drogas ilícitas. Intervenir desde la estrategia legislativa apuntó, en gran medida, a profundizar el castigo hacia el narcocriminal. Las enunciaciones configuraron una maquinaria jurídica sobre la situación de perjuicio a las víctimas. La norma y el castigo aparecieron como desactualizados respecto a la dimensión de la problemática del narcotráfico. A grandes rasgos, los candidatos indicaron que el umbral de tolerancia se franqueó y que el Estado debía reaccionar y accionar a través de la norma. Los candidatos mencionaron la urgencia de modificar la legislación penal para reglamentar castigos a delincuentes. En este sentido, el candidato presidencial fue portavoz de acciones legislativas que podrían promoverse para la lucha contra el narcotráfico. Así, se buscó construir un Estado legislador; un Estado que incluso reviera las penalizaciones al uso de determinadas sustancias.

El discurso político construyó como principal destinatario a la ciudadanía-víctima del delito y la violencia ligados al consumo de drogas, así como tambien del entonces Gobierno debido a su inacción frente al narcotráfico y de las normativas punitivistas contra el consumo de determinadas sustancias ilícitas. Tomando en cuenta la matriz adversativa inherente a los discursos electorales, encontramos que la figura de la víctima del narcotráfico se configuró en función no solo de los riesgos securitarios, sino también de la incapacidad y, hasta cierto punto, de la corrupción del entonces Gobierno. Asimismo, la figura del victimario se depositó como ajeno al nosotros-víctima, así como también en relación con la figura de ciertos funcionarios y autoridades del Estado (jueces corruptos, policías cómplices, políticos de altos mandos, funcionarios del Gobierno) y a los jóvenes consumidores de sustancias. La figura del joven-pobre en los discursos políticos comprende, por un lado, una significación en tanto víctima de la vulnerabilidad social y, por otro, en tanto posible victimario envuelto en acciones de criminalidad urbana. 
Austral Comunicación

Volumen 9, número 2 (Diciembre de 2020):481-518. ISSN 2313-9129

\section{Referencias}

Acosta Jiménez, W. (2013): Historia del tiempo presente del narcotráfico en la cinematografía latinoamericana. En Camarero Calandria, M. E. y Marcos Ramos, M. II Congreso Internacional de Historia, Literatura y Arte en el Cine en español y portugués. De los orígenes a la revolución tecnológica del siglo XXI. Salamanca: Hergar Ediciones Antema.

Agamben, G. (2004). Estado de excepción. Homo Sacer, II, I. Buenos Aires: Adriana Hidalgo.

Ángel, A. (22 de enero de 2018). El año más violento: Los homicidios dolosos aumentaron \%23 de 2016 a 2017. Animal Político. Obtenido de https://www. animalpolitico.com/2018/01/homidicios-dolosos-2017/.

Argentina Debate. (2015a). Argentina Debate 2015 [Archivo de video]. YouTube. Obtenido de https://www.youtube.com/watch?v=bkK8iI2qZVg\&t=1s.

Argentina Debate. (2015b). Argentina Debate 2015. Segunda vuelta: el debate [Archivo de video]. YouTube. Obtenido de https://www.youtube.com/watch?v=susvCR2CF0M.

Aureano, G. (1998). La construction politique du toxicomane dans l'Argentine postautoritaire (Tesis de Doctorado). Université de Montréal. Obtenido de: https:// papyrus.bib.umontreal.ca/xmlui/handle/1866/6787.

Aureano, G. (2004). Uso recreativo de drogas ilícitas, una visión política. En Marcos Cueto Caballero, M. y Cáceres, C. (eds.). La salud como derecho ciudadano perspectivas y propuestas desde América Latina (pp. 44-58). Lima: Redes Jóvenes.

Baquero, R. (2017). El crimen de Brian. La legitimación de la baja en la edad de imputabilidad en el discurso del diario Clarín. Question, 1(56), 1-17.

Beckett, K. (1997). Making crime pay. Nueva York: Oxford University Press.

C5N. (2015). C5N - Economia Política: Programa 27/09/2015 (Parte 3). [Archivo de video]. YouTube. Obtenido de https://www.youtube.com/watch?v=mt1KqhdclD4.

Caimari L, (2012). Mientras la ciudad duerme. Pistoleros, policías y periodistas en Buenos Aires, 1920-1945. Buenos Aires: Siglo XXI.

Calzado, M. (2015). Inseguros: El rol de los medios y la respuesta política frente a la violencia. De Blumberg a hoy. Buenos Aires: Aguilar.

Calzado, M. (2020). Criminología electoral y posicionamientos de campaña: inseguridad, proximidad y liderazgo en las elecciones presidenciales de Argentina de 2015. Palabra Clave, 23(3). https://doi.org/10.5294/pacla.2020.23.3.3.

Calzado, M., Fernández, M. y Lio, V. (2014a). Comunicación, politica y seguridad: La construcción de la violencia urbana en las campañas electorales en la Ciudad de Buenos Aires (2007-2013). Jornadas de Sociología, Universidad Nacional de La Plata, 3 al 5 de diciembre de 2014. Obtenido de http://www.memoria.fahce.unlp. edu.ar/trab_eventos/ev.4272/ev.4272.pdf. 
Cristian Manchego Cárdenas

Luchar contra el narcotráfico: comunicación política electoral sobre las drogas ilícitas en Argentina

Calzado, M., Fernández, M. y Lio, V. (2014b). Ciudad, Delito y Política. El desafío de las izquierdas porteñas frente al debate electoral sobre seguridad urbana. Argumentos. Revista de Crítica Social, (16). Obtenido de https://publicaciones.sociales.uba.ar/ index.php/argumentos/article/view/917/803.

Calzado, M. y Van Den Dooren, S. (2009) ¿Leyes Blumberg? Reclamos sociales de seguridad y reformas penales. Revista Delito y Sociedad, (27), 97-113.

Centro de Estudios Legales y Sociales (2016). La riesgosa política del gobierno para las Fuerzas Armadas, Documento colectivo. Obtenido de https://www.cels.org.ar/web/ wp-content/uploads/2017/03/la_riesgosa_politica_del_gobierno_para_las_ffaa.pdf.

Chevigny, P. (2003). The populism of fear. Politics of crime in the Americas. Punishment\&Society, 5(1).

Cohen, S. (2002). Folk devils and moral panics. Londres: Routledge.

Cunial, S. (2015). El uso de drogas ilegales como asunto de política pública en Argentina. Revista Perspectivas de Políticas Públicas, 4(8). Obtenido de http://revistas.unla. edu.ar/perspectivas/article/view/953.

Dagatti, M. (2018). Imagens da política, política das imagens: sobre comunicação, retórica e estética (Trad. Thiago Augusto Carlos Pereira y Jocenilson Ribeiro). EID\&A - Revista Eletrônica de Estudos Integrados em Discurso e Argumentação, (16), 274-298.

Dallorso, N. y Seghezzo, G. (2015). Inseguridad y política: el miedo como operador estratégico en las campañas electorales. Comunicación $y$ Sociedad, (24), 47-70. Obtenido de http://www.scielo.org.mx/scielo. php?script=sci_arttext\&pid=S0188-252X2015000200003.

Dammert, L. (2009). Drogas e Inseguridad en América Latina: una relación compleja. Nueva Sociedad, (222), 112-131.

Daniel Scioli. (28 de julio de 2015a). Victoria es saber que la lucha contra el narcotráfico no está ganada, pero tampoco está perdida [Archivo de video]. YouTube. Obtenido de https://www.youtube.com/ watch? $\mathrm{v}=$ jnNecDkInrc\&list=PLZLjZ6A02dFP1nXlo2J0dQQ7TUg $\mathrm{xSD} \_$Xw\&index $=8$.

Daniel Scioli. (28 de julio de 2015b). Victoria es que los chicos salgan de la droga y tengan a donde entrar [Archivo de video]. YouTube. Obtenido de https://www. youtube.com/watch?v=ZVFr6KHokqo\&list=PLZLjZ6A02dFP1nXlo2J0dQQ7T UgxSD_Xw\&index $=7$.

Daniel Scioli. (11 de noviembre de 2015). Daniel Scioli - En A Dos Voces. [Archivo de video]. YouTube. Obtenido de https://youtu.be/JgmPkiNlp-A.

Fleitas Ortiz de Rosas, M. (2014). El impacto de la inseguridad en las elecciones. Buenos Aires: Asociación para las Políticas Públicas. 
Austral Comunicación

Volumen 9, número 2 (Diciembre de 2020):481-518. ISSN 2313-9129

Focás, B. (2019). Rutinas de trabajo de los periodistas de noticias policiales de la televisión en Argentina (2011-2015). Comunicación y Sociedad, 16. http://dx.doi. org/10.32870/cys.v2019i0.6822.

Focás, B. y Galar, S. (2016). Inseguridad y medios de comunicación: Prácticas periodísticas y conformación de públicos para el delito en Argentina (2010-2015). Delito y sociedad, 25(41), 59-76.

Foucault, M. (2006). Defender la sociedad. Curso en el Collège de France (1975-1976). Buenos Aires: Fondo de Cultura Económica.

Frederic, S. (2020). Crisis de soberanía y militarización de la Frontera Norte. La fragilidad estatal ante la amenaza de los crímenes organizados en Argentina. Revista CS, (31), 17-42. https://doi.org/10.18046/recs.i31.3724.

Garland, D. (2005). La cultura del control. Barcelona: Gedisa.

Gobierno de Argentina. (2015). Resultados de Elecciones Nacionales. Obtenido de https://www.argentina.gob.ar/interior/dine/resultadosyestadisticas/2015\#7.

Grimson, A. (2006). Nuevas xenofobias, nuevas políticas étnicas en la Argentina. En Grimson, A. y Jelin, E. Migraciones regionales hacia la Argentina. Migraciones regionales hacia la Argentina. Diferencia, desigualdad y derechos. Buenos Aires: Prometeo. Obtenido de https://ccp.ucr.ac.cr/noticias/migraif/pdf/grimson. pdf.

Guemureman, S. (2014). Los "unos" y los "otros": Del tratamiento judicial que reciben los adolescentes y jóvenes que cometen delitos". Revista de la Facultad de Ciencias Sociales, (85), 40-51.

Heram, Y. y Gago, M. (2019). Panelismo y noticia policial. Un análisis sobre la cobertura televisiva del asesinato de Fernando Pastorizzo. Dixit, (30), 4-21. https://doi. org/10.22235/d.v0i30.1722.

Keefer, P. y Loayza, N. (2010). Innocent Bystanders: Developing Countries and the War on Drugs. Washington D.C.: The World Bank/Palgrave Macmillan.

Kornblit, A. L. (2004). Nuevos estudios sobre drogadicción. Consumo e Identidades. Buenos Aires: Biblos.

Koziner, N. (2014). Ni víctimas ni victimarios. Juventud y violencia en los medios masivos de comunicación. Question, (1), 140-148.

Latinobarómetro. (2015). Problema más importante en el país. Obtenido de https:// www.latinobarometro.org/latOnline.jsp.

López, M. (2012). “Vos sos bienvenido, pero ellos no”. Abordaje crítico de los discursos del Jefe de Gobierno de la Ciudad de Buenos Aires, Mauricio Macri, en el contexto de la "toma" del Parque Indoamericano. Revista Isla Flotante, (4), 35-56. Obtenido de http://bibliotecadigital.academia.cl/bitstream/handle/123456789/236/35-56. pdf? sequence $=1$ \&isAllowed $=\mathrm{y}$. 
Cristian Manchego Cárdenas

Luchar contra el narcotráfico: comunicación política electoral sobre las drogas ilícitas en Argentina

Luchessi, L. y Martini, S (2004). Los que hacen la noticia. Periodismo, información y poder. Buenos Aires: Biblos.

Mangone, C. y Warley, J. (1994). El discurso político: del foro a la televisión. Buenos Aires: Biblos.

Manzano, V. (2014). Política, cultura y el "problema de las drogas" en la Argentina, 1960-1980. Apuntes de investigación del CECYP 2014, XVII(24), 51-78.

Martini, S. y Contursi, E. (2012). Introducción. En Martini, S. y Contursi E. (comps.). Comunicación pública del crimen y gestión del control social. Buenos Aires: La Crujía.

Mauricio Macri. (26 de septiembre de 2015). Terminar con el narcotráfico | Mauricio Macri Presidente [Archivo de video]. YouTube. Obtenido de https://www.youtube. com/watch? $=$ YZiXQjBPb20.

Maurici Macri.(13 de octubre de 2015). Erradicar el Paco de toda la Argentina |Mauricio Macri - Gabriela Michetti [Archivo de video]. YouTube. Obtenido de https://www. youtube.com/watch?v=ckI1ctI5JPo.

Mauricio Macri. (19 de noviembre de 2015). En A Dos Voces con Marcelo Bonelli y Edgardo Alfano | Mauricio Macri. [Archivo de video]. YouTube. Obtenido de https://www.youtube.com/watch?v=LWumjPEgep4\&t=36s.

Mera, G. y Vaccotti, L. (2013). Migración y déficit habitacional en la Ciudad de Buenos Aires resignificando el problema. Argumentos, Revista de crítica social, (15), 176202. Obtenido de https://dialnet.unirioja.es/servlet/articulo? codigo $=4549270$.

Mizrahi, E., Callegaro, A., Di Leo Razuk, A., Grasso, A., Namara, R., Quadrini, M. y Val, M. (2018). Pensar el fenómeno narco: El narcotráfico en los discursos audiovisuales (2010-2015). Obtenido de www.jstor.org/stable/j.ctvn96fhr.

Observatorio Comunicación, Política y Seguridad. (14 de octubre de 2016). 2015FPV: Daniel Scioli. Policía Local [Archivo de video]. YouTube. Obtenido de https:// youtu.be/JDontk40OFs.

Observatorio Comunicación, Política y Seguridad. (15 de octubre de 2016a). 2015UNA: SPOT SERGIO MASSA SEGURIDAD AMPLIADA [Archivo de video]. YouTube. Obtenido de https://youtu.be/PzXabpgP7GE.

Observatorio Comunicación, Política y Seguridad. (15 de octubre de 2016b). 2015UNA- Propuesta de seguridad de Massa [Archivo de video]. YouTube. Obtenido de https://youtu.be/k0DHy7wAHqc.

Observatorio Comunicación, Política y Seguridad. (15 de octubre de 2016c). 2015UNA: Sergio Massa. Propuestas seguridad 2015 [Archivo de video]. YouTube. Obtenido de https:/www.youtube.com/watch?v=BSlbu41m2VQ\&ab_ channel=ObservatoriodeComunicaci\%C3\%B3n\%2CPol\%C3\%ADticaySeguridad. 
Austral Comunicación

Volumen 9, número 2 (Diciembre de 2020):481-518. ISSN 2313-9129

Observatorio Comunicación, Política y Seguridad. (15 de octubre de 2016d). 2015UNA: SERGIO MASSA. Miedo por Seguridad [Archivo de video]. YouTube. Obtenido de https://youtu.be/8Uo_81tFXsc.

Observatorio Comunicación, Política y Seguridad. (2 de noviembre de 2016). 2015UNA- Propuesta de seguridad de Massa [Archivo de video]. YouTube. Obtenido de https://www.youtube.com/watch?v=k0DHy7wAHqc\&feature=youtu.be.

Observatorio Comunicación, Política y Seguridad. (2016a). Plataforma electoral. Frente para la Victoria. Año 2015. Obtenido de http://www.comunicacionyseguridad. com/wp-content/uploads/2016/10/1917-1-Plataforma-Electoral-Nacional-2015FpV.pdf.

Observatorio Comunicación, Política y Seguridad. (2016b). Plataforma electoral de Cambiemos. Obtenido de http://www.comunicacionyseguridad.com/wp-content/ uploads/2016/10/plataformaelectoralcambiemos-150921173640-lval-app6891. pdf.

Observatorio Comunicación, Política y Seguridad. (2016c). Plataforma electoral de Progresistas. Obtenido de http://www.comunicacionyseguridad.com/wp-content/ uploads/2016/10/1988-4-PLATAFORMA-PROGRESISTAS-2015.pdf.

Observatorio de Medios del Centro de Estudios Latinoamericanos. (2016). Delito y medios. Obtenido de http://celiv.untref.edu.ar/descargas/Informe_CELIV_2016Delito_y_Medios.pdf.

Pereira, A. (2016). La relación entre seguridad e inmigración durante las primeras décadas del siglo XX en Argentina. Polis, (44). Obtenido de http://journals. openedition.org/polis/11833.

Pitch, T. (2009). Las sociedades de la prevención. Buenos Aires: Ad-Hoc.

Sain, M. (2018). Las Fuerzas Armadas y la Guerra contra las drogas en Argentina. En Tokatlian, J. G. (ed.). De Militares a Policías. La guerra contra las drogas y la militarización de Argentina (pp. 89-198). Buenos Aires: Capital Intelectual.

Sánchez, M. R. (2014). Vivir en la inseguridad. Relatos sobre el delito y el control. La Trama de la Comunicación, 18. Obtenido de https://latrama.fcpolit.unr.edu.ar/ index.php/trama/article/view/471.

Silvera, L. y Natalevich, M. (2012). La crónica policial en los informativos de televisión. Dixit, (16), 4-12.

Simon, J. (2011). Gobernar a través del delito. Barcelona: Gedisa.

Sznaider, B. (2015). De las ciencias sociales, del fenómeno macrista, de la comunicación y de otras yerbas... Revista de la Facultad de Ciencias Sociales, 48, 80-85.

Televisión Pública. (2015). Visión 7 "Tolerencia cero al narcotráfico", prometió Scioli en Rosario [Archivo de video]. YouTube. Obtenido de https://www.youtube.com/ watch?v=yM0e0GJ3rNY. 
Cristian Manchego Cárdenas

Luchar contra el narcotráfico: comunicación política electoral sobre las drogas ilícitas en Argentina

Tokatlian, J. G. (2010a). La guerra antidrogas y el Comando Sur. Revista Foreign Affairs Latinoamérica, 10(1). Obtenido de http://www.agenciacna.com/2/nota_1. php?noticia_id=32076.

Tokatlian, J. G. (2010b).Drogas y prohibición. Una vieja guerra, un nuevo debate. Buenos Aires: Del Zorzal.

Tokatlian, J. G. (2018). Estados Unidos y la militarización del fenómeno de las drogas en América Latina. En Tokatlian, J. G. (ed.). De Militares a Policías. La guerra contra las drogas y la militarización de Argentina (pp. 13-88). Buenos Aires: Capital Intelectual.

Universidad Argentina de la Empresa. (2017). Informe de Opinión Pública CIS UADEVOICES! Obtenido de https://www.uade.edu.ar/media/5dkjsseq/informe-cis2017-n-4-salud-issn-2618-2173.pdf.

Universidad Católica Argentina. (2016). Barómetro del narcotráfico y las adicciones en Argentina. Obtenido de http://wadmin.uca.edu.ar/public/ckeditor/2017Observatorio-Informe-3-Narcotrafico-Addiciones-Venta-Drogas-y-ConsumosProblematicos.pdf.

Verón, E. (1993). La semiosis social. Fragmentos de una teoría de la discursividad. Barcelona: Gedisa.

Verón, E. (1996). La palabra adversativa, Observaciones sobre la enunciación política. Buenos Aires: Hachette.

Verón, E. y Sigal, S. (2003). Perón o muerte. Los fundamentos discursivos del fenómeno peronista. Buenos Aires: Eudeba. 